Supplement of Hydrol. Earth Syst. Sci., 24, 4463-4489, 2020

https://doi.org/10.5194/hess-24-4463-2020-supplement

(c) Author(s) 2020. This work is distributed under

the Creative Commons Attribution 4.0 License.

(c) (1)

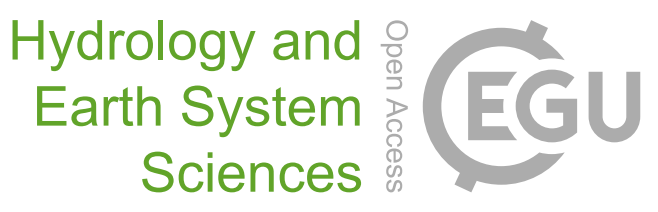

Supplement of

\title{
A systematic assessment of uncertainties in large-scale soil loss estimation from different representations of USLE input factors - a case study for Kenya and Uganda
}

\section{Christoph Schürz et al.}

Correspondence to: Christoph Schürz (christoph.schuerz@boku.ac.at) and Mathew Herrnegger (mathew.herrnegger@boku.ac.at)

The copyright of individual parts of the supplement might differ from the CC BY 4.0 License. 
Supplementary materials for the manuscript: 'A systematic assessment of uncertainties in large scale soil loss estimation from different representations of USLE input factors - A case study for Kenya and Uganda'

This supplementary document provides additional detail on the generation of the USLE model inputs and the data sources that were used for their calculation. Further, the analysis steps and additional results are included here.

\section{Contents}

1 USLE model input factors - Definitions and equations 2

1.1 Rainfall erosivity $\mathrm{f} \ldots \ldots \ldots \ldots \ldots \ldots \ldots$

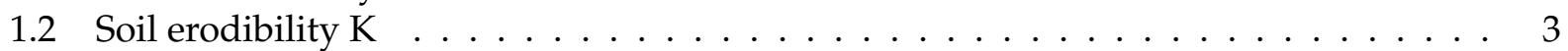

1.3 Slope length and slope steepness LS . . . . . . . . . . . . . . . 7

1.4 Crop cover management $C \ldots \ldots \ldots \ldots \ldots$

2 USLE model input factors - Summary statistics for individual realizations 16

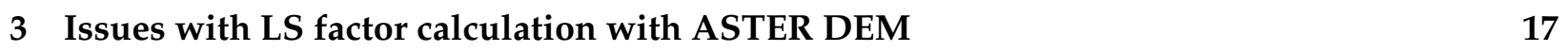

4 Results for mean $C$ values on district level $\quad 19$

5 Results for soil loss on district level $\quad 22$

6 Sensitivity of soil loss estimates to individual input factors $\quad 28$

$\begin{array}{lr}\text { References } & 29\end{array}$ 


\section{S.1 USLE model input factors - Definitions and equations}

The following tables provide an overview of the methods that were implemented to generate the USLE input factor realizations shown in the work-flow in Fig. 2 of the main document. The tables below provide the names of the input realizations as they were used in the main document, the regarding equations and definitions to compute the respective input realizations and references of primary sources and studies that implemented the respective methods.

\section{S.1.1 Rainfall erosivity $R$}

Table S.1 shows the nine realizations for the $R$ factor that were used in the study. The first six methods that were implemented relate $R$ to the annual precipitation $P_{\text {annual }}$. In all cases $P_{\text {annual }}$ was calculated from long-term monthly mean precipitations derived from the WordClim V2 data base (Fick and Hijmans, 2017) that were summarized to annual average sums. The realization $R_{\text {Fenta,MFI }}$ employed the Modified Fournier Index (MFI; Arnoldus, 1980), that was calculated from the long-term monthly precipitation sums derived from the WordClim V2 data base. The realizations $R_{T M P A}$ and $R_{\text {GloREDa }}$ are large scale rainfall erosivity products available upon request from Vrieling et al. (2014) and Panagos et al. (2017), respectively.

Table S.1: Methods to calculate the rainfall erosivity factor $\mathrm{R}$

\begin{tabular}{|c|c|c|}
\hline Realization & Definition & References \\
\hline$R_{\text {Roose }}$ & $\begin{array}{l}R=0.5 \cdot P_{\text {annual }} \cdot 17.3, \text { (value } 17.3 \text { conversion } \\
\text { factor from imperial to SI units ) }\end{array}$ & $\begin{array}{l}\text { Roose (1975), Morgan } \\
\text { (2009) }\end{array}$ \\
\hline$R_{\text {Moore }}$ & $\begin{array}{l}K E_{15}=11.46 \cdot P_{\text {annual }}-2226 \\
R=0.0029 \cdot K E-26.0, R_{S I}=17.02 \cdot R\end{array}$ & Moore (1979) \\
\hline$R_{\text {Lo }}$ & $R=3.48 \cdot P_{\text {annual }}+38.46$ & $\begin{array}{l}\text { Lo et al. (1985), Karamage } \\
\text { et al. (2017) }\end{array}$ \\
\hline$R_{\text {Renard }}$ & $\begin{array}{l}R=0.0483 \cdot P_{\text {annual }}^{1.61}, P_{\text {annual }} \leq 850 \mathrm{~mm} \\
R=587.8-1.219 \cdot P_{\text {annual }}+0.004105 \\
P_{\text {annual }}, P_{\text {annual }} \geq 850 \mathrm{~mm}\end{array}$ & $\begin{array}{l}\text { Renard and Freimund } \\
\text { (1994), Ferro et al. (1991), } \\
\text { Yu and Rosewell (1996), } \\
\text { Naipal et al. (2015), Yang } \\
\text { et al. (2003) }\end{array}$ \\
\hline$R_{\text {Nakil }}$ & $R=839.15 \cdot e^{P_{\text {annuаl }}}$ & Nakil (2014) \\
\hline$R_{\text {Fenta,P }}$ & $R=4.5 \cdot P_{\text {annual }}-661.3$ & $\begin{array}{l}\text { Fenta et al. (2017), Fenta } \\
\text { et al. (2020) }\end{array}$ \\
\hline$R_{\text {Fenta, } M F I}$ & $M F I=\sum_{i=1}^{i=12} \frac{p_{i}^{2}}{P_{\text {anпиа }}}, R=27.8 \cdot M F I-189.2$ & $\begin{array}{l}\text { Arnoldus (1980), Fenta et } \\
\text { al. (2017), Fenta et al. } \\
(2020)\end{array}$ \\
\hline$R_{T M P A}$ & $\begin{array}{l}R \text { estimates for Africa derived from 3-hourly } \\
\text { rainfall TRMM-TMPA data with 0.25-degree } \\
\text { spatial resolution employing the procedure } \\
\text { described in Renard and Freimund (1994) }\end{array}$ & Vrieling et al. (2014) \\
\hline$R_{G l o R E D a}$ & $\begin{array}{l}R \text { estimates from } 3540 \text { stations records } \\
\text { worldwide, using RBF and multiple global } \\
\text { input features for global interpolation on a } \\
1 \mathrm{~km} \text { grid }\end{array}$ & Panagos et al. (2017) \\
\hline
\end{tabular}




\section{S.1.2 Soil erodibility $K$}

To calculate spatial estimates of the Soil erodibility $K$ two global soil data products were implemented SoilGrids250m (Hengl et al., 2017) and the Global Soil Dataset for use in Earth System Models (GSDE, Shangguan et al., 2014). From both products layers of sand, silt, and clay fractions, organic carbon content and coarse soil fractions/rock fragments were acquired for the first $10 \mathrm{~cm}$ and weighted averages over the depths were calculated. Soilgrids $250 \mathrm{~m}$ additionally provides a soil classification layer according to the World Reference Base (WRB) that was used to derive the soil structure.

Table S.2 gives an overview of the six realizations for $K$ that were used in this study. More detail on the equations of the methods are given in in table S.14. The soil structure and soil permeability classifications that were required to compute $K$ employing the method of Wischmeier and Smith (1987) as described in Panagos et al. (2014) are listed in the tables S.4 and S.5.

Table S.2: Methods to calculate soil erodibility K

\begin{tabular}{|c|c|c|}
\hline Realization & Definition & References \\
\hline$K_{\text {SoilGrids,Wischmeie }}$ & $\begin{array}{l}\text { Mean values of sand, silt, and clay fractions for the } \\
\text { soil depths } 0 \text { - 10cm derived from SoilGrids } 250 \mathrm{~m} \\
\text { layers employed in the equation of Wischmeier and } \\
\text { Smith (1987) and applying the corrections } \\
\text { described in Panagos et al. (2014) (additionally } \\
\text { employing the coarse fractions layer from } \\
\text { SoilGrids250m). The soil structure s was derived } \\
\text { from the World Reference Base (WRB) soil } \\
\text { classification layer available from SoilGrids250m } \\
\text { and a corresponding structure classification based } \\
\text { on Baruth et al. (2006) as described in Panagos et } \\
\text { al. (2014) or Borrelli et al. (2017) }\end{array}$ & $\begin{array}{l}\text { Panagos et al. (2014), } \\
\text { Panagos et al. (2015c), } \\
\text { Borrelli et al. (2017) }\end{array}$ \\
\hline$K_{\text {SoilGrids,Williams }}$ & $\begin{array}{l}\text { Mean values of sand, silt, clay, and organic carbon } \\
\text { percentages for the soil depths } 0 \text { - } 10 \mathrm{~cm} \text { derived } \\
\text { from SoilGrids } 250 \mathrm{~m} \text { layers employed in the } \\
\text { equation of Williams (1995) }\end{array}$ & $\begin{array}{l}\text { Karamage et al. } \\
\text { (2017), Yang et al. } \\
(2003)\end{array}$ \\
\hline$K_{\text {SoilGrids,Torri }}$ & $\begin{array}{l}\text { Mean values of sand, silt, clay, and organic carbon } \\
\text { fractions for the soil depths } 0-10 \mathrm{~cm} \text { derived from } \\
\text { SoilGrids } 250 \mathrm{~m} \text { layers employed in the equation of } \\
\text { Torri et al. (1997) }\end{array}$ & $\begin{array}{l}\text { Yang et al. (2003), } \\
\text { Naipal et al. (2015), } \\
\text { Torri et al. (1997) }\end{array}$ \\
\hline$K_{G S D E, \text { Wischmeier }}$ & $\begin{array}{l}\text { Mean values of sand, silt, and clay fractions for the } \\
\text { soil depths } 0-10 \mathrm{~cm} \text { derived from SoilGrids } 250 \mathrm{~m} \\
\text { layers employed in the equation of Wischmeier and } \\
\text { Smith (1987) and applying the corrections } \\
\text { described in Panagos et al. (2014) (additionally } \\
\text { employing the coarse fractions layer from GSDE). } \\
\text { The soil structure s and permeability p were set to } 2 \\
\text { and } 3 \text { as default values, respectively, as shown in } \\
\text { Tamene and Le (2015) }\end{array}$ & Tamene and Le (2015) \\
\hline
\end{tabular}




\begin{tabular}{lll}
\hline Realization & Definition & References \\
\hline$K_{\text {GSDE,Williams }}$ & $\begin{array}{l}\text { Mean values of sand, silt, and clay fractions for the } \\
\text { soil depths 0 - 10cm derived from GSDE layers } \\
\text { employed in the equation of Williams (1995) }\end{array}$ & Yang et al. (2003) \\
& $\begin{array}{l}\text { Mean values of sand, silt, clay, and organic carbon } \\
\text { fractions for the soil depths 0 - 10cm derived from }\end{array}$ & $\begin{array}{l}\text { Yang et al. (2003), } \\
\text { GSDE,Torri }\end{array}$ \\
& $\begin{array}{l}\text { GSDE layers employed in the equation of Torri et } \\
\text { al. (1997) }\end{array}$ & $\begin{array}{l}\text { Torri et al. (1997) } \\
\end{array}$ \\
\hline
\end{tabular}

Table S.14 provides the equations for the three implemented methods of Wischmeier and Smith (1987), Williams (1995), and Torri et al. (1997). The inputs that are required in the respective methods to compute $\mathrm{K}$ are the mass fractions (in percent) of Sand $m_{\text {Sand }}$, Silt $m_{\text {Silt }}$, Clay $m_{\text {Clay }}$, and organic matter/carbon content $\operatorname{org} C$.

Table S.3: Summary of the K factor realizations

\begin{tabular}{|c|c|}
\hline Author & Equations \\
\hline Wischmeier and Smith & $K=0.1317 \cdot \frac{0.00021 \cdot M^{1.14} \cdot(12-\operatorname{org} C)+3.25 \cdot(s-2)+2.5 \cdot(p-3)}{100}$, \\
\hline$(1987)$ & $M=\left(m_{\text {Silt }}+m_{v f \text { Sand }}\right) *\left(100-m_{\text {Clay }}\right)$ \\
\hline \multirow[t]{4}{*}{ Williams (1995) } & $K=0.1317 \cdot f_{c \text { Sand }} \cdot f_{C l-S i} \cdot f_{\text {orgC }} \cdot f_{\text {hiSand }}$, \\
\hline & $\begin{array}{l}f_{\text {CSand }}=0.2 \cdot 0.3 e^{-0.0256 \cdot m_{S a} \cdot\left(1-\frac{m_{\text {Silt }}}{100}\right)} \\
f_{C l-S i}=\frac{m_{\text {Silt }}}{m_{\text {Clay }}+m_{\text {Silt }}}\end{array}$ \\
\hline & $f_{\operatorname{org} C}=1-\frac{0.0256 \cdot \text { orgC }}{\operatorname{org} C+e^{3.72-2.95 \cdot \text { org } C}}$ \\
\hline & $\begin{array}{l}f_{\text {hiSand }}=1-\frac{0.7 \cdot S N}{S N+e^{-5.51+22.9 \cdot S N}} \\
S N=1-\frac{m_{\text {Sand }}}{100}\end{array}$ \\
\hline Torri et al. (1997) & $0.0293 \cdot\left(0.65-D_{g}+0.24 \cdot D_{g}^{2}\right) \cdot f_{\text {orgC,Clay, }}$ \\
\hline & $\begin{array}{l}D_{g}=0.01 \cdot\left(-3.5 \cdot m_{\text {Sand }}-2.0 \cdot m_{\text {Silt }}-0.5 \cdot m_{\text {Clay }}\right), \\
f_{\text {orgC }, \text { Clay }}=e^{-0.0021 \cdot \frac{\text { orgC }}{m_{\text {Clay }} / 100}-0.00037 \cdot\left(\frac{\text { orgC }}{m_{\text {Clay }} 1100}\right)^{2}-4.02 \cdot \frac{m_{\text {Clay }}}{100}+1.71 \cdot\left(\frac{m_{\text {Clay }}}{100}\right)^{2}}\end{array}$ \\
\hline
\end{tabular}

Table S.4: Lookup table to derive the soil structure s from the soil taxonomy classification according to WRB

\begin{tabular}{rlllr}
\hline WRB value & Soil name & Qualifier & Soil group & Structure class s \\
\hline 1 & Haplic Acrisols & Haplic & AC & 2 \\
2 & Haplic Acrisols (Alumic) & Haplic & AC & 2 \\
3 & Haplic Acrisols (Ferric) & Haplic & AC & 2 \\
4 & Haplic Acrisols (Humic) & Haplic & AC & 4 \\
5 & Plinthic Acrisols & Plinthic & AC & 2 \\
6 & Vetic Acrisols & Vetic & AC & 2 \\
7 & Haplic Albeluvisols & Haplic & AB & 2 \\
8 & Histic Albeluvisols & Histic & AB & 2 \\
9 & Umbric Albeluvisols & Umbric & AB & 2 \\
10 & Cutanic Alisols & Cutanic & AL & 2
\end{tabular}




\begin{tabular}{|c|c|c|c|c|}
\hline WRB value & Soil name & Qualifier & Soil group & Structure class s \\
\hline 11 & Haplic Alisols & Haplic & $\mathrm{AL}$ & 2 \\
\hline 12 & Aluandic Andosols & Aluandic & AN & 1 \\
\hline 13 & Haplic Andosols & Haplic & AN & 1 \\
\hline 14 & Vitric Andosols & Vitric & $\mathrm{AN}$ & 1 \\
\hline 15 & Albic Arenosols & Albic & AR & 2 \\
\hline 16 & Ferralic Arenosols & Ferralic & AR & 2 \\
\hline 17 & Haplic Arenosols & Haplic & AR & 2 \\
\hline 18 & Haplic Arenosols (Calcaric) & Haplic & AR & 2 \\
\hline 19 & Hypoluvic Arenosols & Hypoluvic & AR & 2 \\
\hline 20 & Protic Arenosols & Protic & $\mathrm{AR}$ & 2 \\
\hline 21 & Haplic Calcisols & Haplic & $\mathrm{CL}$ & 2 \\
\hline 22 & Haplic Calcisols (Sodic) & Haplic & CL & 2 \\
\hline 23 & Luvic Calcisols & Luvic & $\mathrm{CL}$ & 2 \\
\hline 24 & Petric Calcisols & Petric & CL & 2 \\
\hline 25 & Endogleyic Cambisols & Endogleyic & $\mathrm{CM}$ & 4 \\
\hline 26 & Ferralic Cambisols & Ferralic & $\mathrm{CM}$ & 2 \\
\hline 27 & Haplic Cambisols & Haplic & $\mathrm{CM}$ & 2 \\
\hline 28 & Haplic Cambisols (Calcaric) & Haplic & $\mathrm{CM}$ & 1 \\
\hline 29 & $\begin{array}{l}\text { Haplic Cambisols } \\
\text { (Chromic) }\end{array}$ & Haplic & $\mathrm{CM}$ & 1 \\
\hline 30 & Haplic Cambisols (Dystric) & Haplic & $\mathrm{CM}$ & 1 \\
\hline 31 & Haplic Cambisols (Eutric) & Haplic & $\mathrm{CM}$ & 1 \\
\hline 32 & Haplic Cambisols (Humic) & Haplic & $\mathrm{CM}$ & 4 \\
\hline 33 & Haplic Cambisols (Sodic) & Haplic & $\mathrm{CM}$ & 1 \\
\hline 34 & Leptic Cambisols & Leptic & $\mathrm{CM}$ & 1 \\
\hline 35 & Vertic Cambisols & Vertic & $\mathrm{CM}$ & 1 \\
\hline 36 & Calcic Chernozems & Calcic & $\mathrm{CH}$ & 2 \\
\hline 37 & Haplic Chernozems & Haplic & $\mathrm{CH}$ & 2 \\
\hline 38 & Luvic Chernozems & Luvic & $\mathrm{CH}$ & 2 \\
\hline 39 & Haplic Cryosols & Haplic & CR & 2 \\
\hline 40 & Turbic Cryosols & Turbic & CR & 2 \\
\hline 41 & Vitric Cryosols & Vitric & $\mathrm{CR}$ & 2 \\
\hline 42 & Petric Durisols & Petric & DU & 2 \\
\hline 43 & Acric Ferralsols & Acric & FR & 2 \\
\hline 44 & Haplic Ferralsols & Haplic & FR & 2 \\
\hline 45 & Haplic Ferralsols (Rhodic) & Haplic & FR & 2 \\
\hline 46 & Haplic Ferralsols (Xanthic) & Haplic & FR & 2 \\
\hline 47 & Umbric Ferralsols & Umbric & FR & 2 \\
\hline 48 & Haplic Fluvisols & Haplic & FL & 2 \\
\hline 49 & Haplic Fluvisols (Arenic) & Haplic & FL & 2 \\
\hline 50 & Haplic Fluvisols (Calcaric) & Haplic & FL & 2 \\
\hline 51 & Haplic Fluvisols (Dystric) & Haplic & FL & 2 \\
\hline 52 & Haplic Fluvisols (Eutric) & Haplic & FL & 2 \\
\hline 53 & Calcic Gleysols & Calcic & GL & 2 \\
\hline 54 & Haplic Gleysols & Haplic & GL & 2 \\
\hline 55 & Haplic Gleysols (Dystric) & Haplic & GL & 2 \\
\hline
\end{tabular}




\begin{tabular}{|c|c|c|c|c|}
\hline WRB value & Soil name & Qualifier & Soil group & Structure class s \\
\hline 56 & Haplic Gleysols (Eutric) & Haplic & GL & 2 \\
\hline 57 & Mollic Gleysols & Mollic & GL & 4 \\
\hline 58 & Umbric Gleysols & Umbric & GL & 2 \\
\hline 59 & Calcic Gypsisols & Calcic & GY & 2 \\
\hline 60 & Haplic Gypsisols & Haplic & GY & 2 \\
\hline 61 & Calcic Histosols & Calcic & HS & 4 \\
\hline 62 & Cryic Histosols & Cryic & HS & 4 \\
\hline 63 & Fibric Histosols & Fibric & HS & 4 \\
\hline 64 & Hemic Histosols & Hemic & HS & 4 \\
\hline 65 & Sapric Histosols & Sapric & HS & 4 \\
\hline 66 & Calcic Kastanozems & Calcic & KS & 2 \\
\hline 67 & Haplic Kastanozems & Haplic & KS & 2 \\
\hline 68 & Haplic Leptosols & Haplic & $\mathrm{LP}$ & 2 \\
\hline 69 & Haplic Leptosols (Eutric) & Haplic & LP & 2 \\
\hline 70 & Lithic Leptosols & Lithic & LP & 2 \\
\hline 71 & Mollic Leptosols & Mollic & LP & 2 \\
\hline 72 & Rendzic Leptosols & Rendzic & $\mathrm{LP}$ & 4 \\
\hline 73 & Haplic Lixisols & Haplic & LX & 2 \\
\hline 74 & Haplic Lixisols (Chromic) & Haplic & LX & 2 \\
\hline 75 & Haplic Lixisols (Ferric) & Haplic & LX & 2 \\
\hline 76 & Albic Luvisols & Albic & LV & 2 \\
\hline 77 & Calcic Luvisols & Calcic & $\mathrm{LV}$ & 2 \\
\hline 78 & Gleyic Luvisols & Gleyic & LV & 2 \\
\hline 79 & Haplic Luvisols & Haplic & $\mathrm{LV}$ & 2 \\
\hline 80 & Haplic Luvisols (Chromic) & Haplic & LV & 2 \\
\hline 81 & Haplic Luvisols (Ferric) & Haplic & $\mathrm{LV}$ & 2 \\
\hline 82 & Leptic Luvisols & Leptic & $\mathrm{LV}$ & 2 \\
\hline 83 & Stagnic Luvisols & Stagnic & $\mathrm{LV}$ & 2 \\
\hline 84 & Vertic Luvisols & Vertic & LV & 2 \\
\hline 85 & Alic Nitisols & Alic & NT & 2 \\
\hline 86 & Haplic Nitisols (Rhodic) & Haplic & NT & 1 \\
\hline 87 & Haplic Phaeozems & Haplic & $\mathrm{PH}$ & 1 \\
\hline 88 & Leptic Phaeozems & Leptic & $\mathrm{PH}$ & 2 \\
\hline 89 & Luvic Phaeozems & Luvic & $\mathrm{PH}$ & 4 \\
\hline 90 & Endogleyic Planosols & Endogleyic & PL & 2 \\
\hline 91 & Haplic Planosols (Dystric) & Haplic & PL & 2 \\
\hline 92 & Haplic Planosols (Eutric) & Haplic & PL & 2 \\
\hline 93 & Luvic Planosols & Luvic & PL & 2 \\
\hline 94 & Solodic Planosols & Solodic & PL & 2 \\
\hline 95 & Acric Plinthosols & Acric & PT & 2 \\
\hline 96 & Lixic Plinthosols & Lixic & PT & 2 \\
\hline 97 & Gleyic Podzols & Gleyic & PZ & 2 \\
\hline 98 & Haplic Podzols & Haplic & $\mathrm{PZ}$ & 2 \\
\hline 99 & Aric Regosols & Aric & RG & 2 \\
\hline 100 & Calcaric Regosols & Calcaric & RG & 2 \\
\hline 101 & Haplic Regosols (Dystric) & Haplic & RG & 2 \\
\hline
\end{tabular}




\begin{tabular}{rlllr}
\hline WRB value & Soil name & Qualifier & Soil group & Structure class s \\
\hline 102 & Haplic Regosols (Eutric) & Haplic & RG & 2 \\
103 & Haplic Regosols (Sodic) & Haplic & RG & 2 \\
104 & Leptic Regosols & Leptic & RG & 2 \\
105 & Gypsic Solonchaks & Gypsic & SC & 2 \\
106 & Haplic Solonchaks & Haplic & SC & 2 \\
107 & Haplic Solonchaks (Sodic) & Haplic & SC & 2 \\
108 & Calcic Solonetz & Calcic & SN & 2 \\
109 & Gleyic Solonetz & Gleyic & SN & 2 \\
110 & Haplic Solonetz & Haplic & SN & 2 \\
111 & Mollic Solonetz & Mollic & SN & 1 \\
112 & Luvic Stagnosols & Luvic & ST & 4 \\
113 & Haplic Umbrisols & Haplic & UM & 4 \\
114 & Leptic Umbrisols & Leptic & UM & 1 \\
115 & Calcic Vertisols & Calcic & VR & 2 \\
116 & Haplic Vertisols & Haplic & VR & 2 \\
117 & Haplic Vertisols (Eutric) & Haplic & VR & 2 \\
118 & Mollic Vertisols & Mollic & VR & 2 \\
\hline
\end{tabular}

Table S.5: Lookup table to derive the soil permeability $\mathrm{p}$ from the USDA soil texture classification

\begin{tabular}{rlr}
\hline Value & USDA texture class & Permeability class $\mathrm{p}$ \\
\hline 1 & Clay & 6 \\
2 & Silty Clay & 6 \\
3 & Sandy Clay & 5 \\
4 & Silty Clay Loam & 5 \\
5 & Clay Loam & 4 \\
6 & Sandy Clay Loam & 4 \\
7 & Silt & 3 \\
8 & Silty Loam & 3 \\
9 & Loam & 3 \\
10 & Sandy Loam & 2 \\
11 & Loamy Sand & 2 \\
12 & Sand & 1 \\
\hline
\end{tabular}

\section{S.1.3 Slope length and slope steepness $L S$}

The calculation of the LS factor was based on two global elevation products the SRTM90m V4.1 (Jarvis et al., 2008) and the ASTER GDEM V4 (NASA/METI/AIST/Japan Spacesystems, and U.S./Japan ASTER Science Team, 2009) with a spatial resolution of 30m. Computational limitations required a resampling of the ASTER 30m DEM to the extent of the 90m grid of SRTM90m V4.1. Corrections of the input layers as recommended and performed in Panagos et al. (2015a) were considered for both input DEM layers.

Both input layers were pre-processed and prepared for the computation of LS. A DEM fill 
and the flow direction calculation was performed according to Wang and Liu (2006). Flow accumulation and contributing catchment areas were calculated with the methods of Freeman (1991) and Quinn et al. (1991). Spatial slope estimates for both DEM products were calculated with the method of Zevenbergen and Thorne (1987). The pre-processing of the input DEM layers was done in ArcGIS 10.2 (ESRI, 2012).

To compute the LS factor realizations the methods of Moore et al. (1991), Desmet and Govers (1996), and Böhner and Selige (2006) were applied using the pre-processed layers based on SRTM90m and ASTER GDEM. For details to the methods we refer to the respective literature and will not repeat the methods' equations here. All implemented methods are available from the LS calculation module in SAGA GIS V2.1.4 (Conrad et al., 2015). Table S.6 gives an overview of the six realizations for $K$ that were used in this study.

Table S.6: Summary of the LS factor realizations

\begin{tabular}{|c|c|c|}
\hline Realization & Definition & References \\
\hline$L S_{S R T M, \text { Moore }}$ & $\begin{array}{l}\text { Slope and Catchment Area derived from SRTM90m } \\
\text { V4.1 implemented in the method of Moore et al. (1991) }\end{array}$ & et al. (2015) \\
\hline$L S_{S R T M, D e s m e t}$ & $\begin{array}{l}\text { Slope and Catchment Area derived from SRTM90m } \\
\text { V4.1 implemented in the method of Desmet and Govers } \\
\text { (1996) }\end{array}$ & $\begin{array}{l}\text { Borrelli et al. } \\
(2017)\end{array}$ \\
\hline$L S_{S R T M, B o e h n e r}$ & $\begin{array}{l}\text { Slope and Catchment Area derived from SRTM90m V4.1 } \\
\text { implemented in the method of Böhner and Selige (2006) }\end{array}$ & - \\
\hline$L S_{A S T E R, M o o r e}$ & $\begin{array}{l}\text { Slope and Catchment Area derived from ASTER GDEM } \\
\text { V4 implemented in the method of Moore et al. (1991) }\end{array}$ & Bosco et al. (2015) \\
\hline$L S_{A S T E R, D e s m e t}$ & $\begin{array}{l}\text { Slope and Catchment Area derived from ASTER GDEM } \\
\text { V4 implemented in the method of Desmet and Govers } \\
\text { (1996) }\end{array}$ & $\begin{array}{l}\text { Karamage et al. } \\
\text { (2017), Borrelli et } \\
\text { al. (2017) }\end{array}$ \\
\hline$L S_{A S T E R, B o e h n e r}$ & $\begin{array}{l}\text { Slope and Catchment Area derived from ASTER GDEM } \\
\text { V4 implemented in the method of Böhner and Selige } \\
\text { (2006) }\end{array}$ & - \\
\hline
\end{tabular}

\section{S.1.4 Crop cover management $C$}

To compute the $C$ we applied two different approaches. One approach estimates the $C$-factor from vegetation indices that are readily available from satellite based remote sensing. The majority of applications in literature that we found utilized the normalized difference vegetation index (NDVI) to assess C (e.g. Karamage et al., 2017; Naipal et al., 2015) and applied the method proposed by Van der Knijff et al. (2000):

$$
C=\exp \left(-\alpha \frac{N D V I}{\beta-N D V I}\right)
$$

with $\alpha=1$ and $\beta=2$, involving different temporal aggregates of the MODIS NDVI (Didan, 2015). MODIS NDVI provides 16 day averages. Spatially distributed mean NDVI estimates were calculated on annual basis and for the rainy season based on the 16 day averages for the time period 2000 to 2012. These mean NDVI estimates were used in the equation above to compute two spatially distributed realizations of the $C$ factor. 
The second approach relates land uses classified in land cover products and agricultural statistics to $C$ values derived from field experiments (e.g. Borrelli et al., 2017; Panagos et al., 2015b; Yang et al., 2003). Two agricultural statistics products were implemented, a global product of spatially distributed crop shares provided by Monfreda et al. (2008) and agricultural surveys in Kenya and Uganda (KNBS, 2015; UBOS, 2010). In their global study Borrelli et al. (2017) grouped the crops available from Monfreda et al. (2008) and assigned $C$ factor literature values. We used the same crop grouping that is summarized in table S.7. We employed $C$ factor literature values that were available from Borrelli et al. (2017), Panagos et al. (2015b), Angima et al. (2003). Table S.8 shows the $C$ factor literature values for specific crop groups adapted from Borrelli et al. (2017) that were used in this study.

Table S.7: Grouping of crops available from Monfreda et al.

(2008) based on Borrelli et al. (2017)

\begin{tabular}{|c|c|c|}
\hline Group ID & Crop & Label \\
\hline 11 & Manila fibre (abaca) & abaca \\
\hline 11 & Agave fibres nes & agave \\
\hline 8.2 & Forage and silage, alfalfa & alfalfa \\
\hline 14 & Almonds, with shell & almond \\
\hline 7 & Anise, badian, fennel, coriander & aniseetc \\
\hline 14 & Apples & apple \\
\hline 14 & Apricots & apricot \\
\hline 14 & Areca nuts & areca \\
\hline 4 & Artichokes & artichoke \\
\hline 6 & Asparagus & asparagus \\
\hline 14 & Avocados & avocado \\
\hline 2 & Bambara beans & bambara \\
\hline 14 & Bananas & banana \\
\hline 1 & Barley & barley \\
\hline 2 & Beans, dry & bean \\
\hline 3 & Beets for fodder & beetfor \\
\hline 12 & Berries nes & berrynes \\
\hline 12 & Blueberries & blueberry \\
\hline 14 & Brazil nuts, with shell & brazil \\
\hline 2 & Broad beans, horse beans, dry & broadbean \\
\hline 1 & Buckwheat & buckwheat \\
\hline 7 & Cabbages and other brassicas & cabbage \\
\hline 7 & Cabbage for fodder & cabbagefor \\
\hline 10 & Canary seed & canaryseed \\
\hline 14 & Carobs & carob \\
\hline 3 & Carrots and turnips & carrot \\
\hline 3 & Carrots for fodder & carrotfor \\
\hline 14 & Cashew nuts, with shell & cashew \\
\hline 14 & Cashew apple & cashewapple \\
\hline 3 & Cassava & cassava \\
\hline 10 & Castor oil seed & castor \\
\hline 7 & Cauliflowers and broccoli & cauliflower \\
\hline
\end{tabular}




\begin{tabular}{|c|c|c|}
\hline Group ID & Crop & Label \\
\hline 1 & Cereals, nes & cerealnes \\
\hline 14 & Cherries & cherry \\
\hline 14 & Chestnut & chestnut \\
\hline 2 & Chick peas & chickpea \\
\hline 3 & Chicory roots & chicory \\
\hline 4 & Chillies and peppers, green & chilleetc \\
\hline 13.1 & Cinnamon (canella) & cinnamon \\
\hline 14 & Fruit, citrus nes & citrusnes \\
\hline 13.1 & Cloves & clove \\
\hline 8.1 & Forage and silage, clover & clover \\
\hline 14 & Cocoa, beans & cocoa \\
\hline 14 & Coconuts & coconut \\
\hline 13.2 & Coffee, green & coffee \\
\hline 11 & Coir & coir \\
\hline 10.1 & Seed cotton & cotton \\
\hline 2 & Cow peas, dry & cowpea \\
\hline 12 & Cranberries & cranberry \\
\hline 5 & Cucumbers and gherkins & cucumberetc \\
\hline 12 & Currants & currant \\
\hline 14 & Dates & date \\
\hline 4 & Eggplants (aubergines) & eggplant \\
\hline 11 & Fibre crops nes & fibrenes \\
\hline 14 & Figs & fig \\
\hline 11 & Flax fibre and tow & flax \\
\hline 1 & Fonio & fonio \\
\hline 8.2 & Forage products & fornes \\
\hline 14 & Fruit, fresh nes & fruitnes \\
\hline 6 & Garlic & garlic \\
\hline 3 & Ginger & ginger \\
\hline 12 & Gooseberries & gooseberry \\
\hline 9.1 & Grapes & grape \\
\hline 14 & Grapefruit (inc. pomelos) & grapefruitetc \\
\hline 8.1 & Forage and silage, grasses nes & grassnes \\
\hline 2 & Beans, green & greenbean \\
\hline 2 & Leguminous vegetables, nes & greenbroadbean \\
\hline 1.1 & Maize, green & greencorn \\
\hline 6 & Onions, shallots, green & greenonion \\
\hline 2 & Peas, green & greenpea \\
\hline 2 & Groundnuts, with shell & groundnut \\
\hline 14 & Gums & gums \\
\hline 14 & Hazelnuts, with shell & hazelnut \\
\hline 13.1 & Hemp tow waste & hemp \\
\hline 13.1 & Hempseed & hempseed \\
\hline 9.2 & Hops & hop \\
\hline 11 & Jute & jute \\
\hline 11 & Bastfibres, other & jutelikefiber \\
\hline
\end{tabular}




\begin{tabular}{|c|c|c|}
\hline Group ID & Crop & Label \\
\hline 11 & Kapok fibre & kapokfiber \\
\hline 14 & Kapok fruit & kapokseed \\
\hline 14 & Karite nuts (sheanuts) & karite \\
\hline 14 & Kiwi fruit & kiwi \\
\hline 14 & Kola nuts & kolanut \\
\hline 8.1 & Forage and silage, legumes & legumenes \\
\hline 14 & Lemons and limes & lemonlime \\
\hline 2 & Lentils & lentil \\
\hline 7 & Lettuce and chicory & lettuce \\
\hline 10 & Linseed & linseed \\
\hline 2 & Lupins & lupin \\
\hline 1.1 & Maize & maize \\
\hline 8.1 & Forage and silage, maize & maizefor \\
\hline 14 & Mangoes, mangosteens, guavas & mango \\
\hline 13.1 & Maté & mate \\
\hline 5 & Melons, other (inc.cantaloupes) & melonetc \\
\hline 5 & Melonseed & melonseed \\
\hline 1 & Millet & millet \\
\hline 1 & Mixed grain & mixedgrain \\
\hline 10 & Mustard seed & mustard \\
\hline 13.1 & Nutmeg, mace and cardamoms & nutmeg \\
\hline 14 & Nuts, nes & nutnes \\
\hline 1 & Oats & oats \\
\hline 14 & Oil, palm fruit & oilpalm \\
\hline 8.2 & Forage and silage, green oilseeds & oilseedfor \\
\hline 10 & Oilseeds nes & oilseednes \\
\hline 4 & Okra & okra \\
\hline 14 & Olives & olive \\
\hline 6 & Onions, dry & onion \\
\hline 14 & Oranges & orange \\
\hline 14 & Papayas & papaya \\
\hline 2 & Peas, dry & pea \\
\hline 14 & Peaches and nectarines & peachetc \\
\hline 14 & Pears & pear \\
\hline 4 & Pepper (piper spp.) & pepper \\
\hline 13.1 & Peppermint & peppermint \\
\hline 14 & Persimmons & persimmon \\
\hline 2 & Pigeon peas & pigeonpea \\
\hline 4 & Chillies and peppers, dry & pimento \\
\hline 14 & Pineapples & pineapple \\
\hline 14 & Pistachios & pistachio \\
\hline 14 & Plantains & plantain \\
\hline 14 & Plums and sloes & plum \\
\hline 1.1 & Popcorn & popcorn \\
\hline 10 & Poppy seed & poppy \\
\hline 3 & Potatoes & potato \\
\hline
\end{tabular}




\begin{tabular}{|c|c|c|}
\hline Group ID & Crop & Label \\
\hline 2 & Pulses, nes & pulsenes \\
\hline 5 & Pumpkins, squash and gourds & pumpkinetc \\
\hline 13.1 & Pyrethrum, dried & pyrethrum \\
\hline 14 & Quinces & quince \\
\hline 7 & Quinoa & quinoa \\
\hline 13.1 & Ramie & ramie \\
\hline 10 & Rapeseed & rapeseed \\
\hline 12 & Raspberries & rasberry \\
\hline 1.2 & Rice, paddy & rice \\
\hline 3 & Roots and tubers, nes & rootnes \\
\hline 14 & Rubber, natural & rubber \\
\hline 1 & Rye & rye \\
\hline 8.2 & Forage and silage, rye grass & ryefor \\
\hline 10 & Safflower seed & safflower \\
\hline 10 & Sesame seed & sesame \\
\hline 11 & Sisal & sisal \\
\hline 1 & Sorghum & sorghum \\
\hline 8.2 & Forage and silage, sorghum & sorghumfor \\
\hline 14 & Cherry sour & sourcherry \\
\hline 2 & Soybeans & soybean \\
\hline 13.1 & Spices, nes & spicenes \\
\hline 7 & Spinach & spinach \\
\hline 14 & Fruit, stone nes & stonefruitnes \\
\hline 12.1 & Strawberries & strawberry \\
\hline 2 & String beans & stringbean \\
\hline 3 & Sugar beet & sugarbeet \\
\hline 13.1 & Sugar cane & sugarcane \\
\hline 13.1 & Sugar crops, nes & sugarnes \\
\hline 10 & Sunflower seed & sunflower \\
\hline 3 & Swedes for fodder & swedefor \\
\hline 3 & Sweet potatoes & sweetpotato \\
\hline 14 & $\begin{array}{l}\text { Tangerines, mandarins, clementines, } \\
\text { satsumas }\end{array}$ & tangetc \\
\hline 3 & Taro (cocoyam) & taro \\
\hline 13.1 & Tea $(0.1-0.2)$ & tea \\
\hline 7.1 & Tobacco, unmanufactured & tobacco \\
\hline 4 & Tomatoes & tomato \\
\hline 1 & Triticale & triticale \\
\hline 14 & Fruit, tropical fresh nes & tropicalnes \\
\hline 14 & Tung nuts & tung \\
\hline 3 & Turnips for fodder & turnipfor \\
\hline 13.1 & Vanilla & vanilla \\
\hline 7 & Vegetables, fresh nes & vegetablenes \\
\hline 3 & Vegetables and roots fodder & vegfor \\
\hline 2 & Vetches & vetch \\
\hline 14 & Walnuts, with shell & walnut \\
\hline
\end{tabular}




\begin{tabular}{rll}
\hline Group ID & Crop & Label \\
\hline 5 & Watermelons & watermelon \\
1 & Wheat & wheat \\
3 & Yams & yam \\
3 & Yautia (cocoyam) & yautia \\
8.2 & Mixed grass & mixedgrass \\
4 & Mushrooms & mushroom \\
\hline
\end{tabular}

Table S.8: C factor literature values for specific crop groups based on Borrelli et al. (2017)

\begin{tabular}{rlrr}
\hline Group ID & Crop group & Label & C \\
\hline 1 & Cereal Grains & cereal & 0.2 \\
1.1 & Maize & maize & 0.38 \\
1.2 & Rice & rice & 0.15 \\
2 & Legume Vegetables & veg_legume & 0.32 \\
3 & Root and Tuber Vegetables & veg_root & 0.34 \\
4 & Fruit Vegetables & veg_fruit & 0.25 \\
5 & Cucurbit Vegetables & veg_cucurbit & 0.25 \\
6 & Bulb Vegetables & veg_bulb & 0.3 \\
7 & Leafy Vegetables & veg_leaf & 0.25 \\
7.1 & Tobacco & tobacco & 0.5 \\
8.1 & Mixed Legumes & for_legume & 0.15 \\
8.2 & Mixed grasses & for_grass & 0.1 \\
9.1 & Grapes & grape & 0.35 \\
9.2 & Hops & hop & 0.42 \\
10 & Oilseed Group & oilseed & 0.25 \\
10.1 & Cotton & cotton & 0.4 \\
11 & Fibre Crops & fibre & 0.28 \\
12 & Berries Group & berry & 0.15 \\
12.1 & Strawberries & strawberry & 0.2 \\
13.1 & Shrubs Herbs and Spices & herb_spice & 0.15 \\
13.2 & Coffee & coffee & 0.2 \\
14 & Trees/Fruit Tree & tree & 0.15 \\
\hline & & &
\end{tabular}

Implementing the approach of Panagos2015, we calculated spatially distributed weighted average $\mathrm{C}$-factor values for agricultural areas in the study domain based on the crop shares that were available from Monfreda et al. (2008) and the national agricultural surveys:

$$
C_{(x, y)}=\sum_{i=1}^{n} C_{i} \cdot \text { fraction }_{i,(x, y)}
$$

where $C_{(x, y)}$ is the weighted C-factor for the location $(x, y), C_{i}$ is the C-factor of the crop $i, n$ is the total number of crops, and fraction $_{i,(x, y)}$ is the calculated fraction of the area cultivated with crop $i$ at the location $(x, y)$. 
The calculated average $C$ values according to the crop shares were superimposed with the two land cover products MODIS Land Cover (Channan et al., 2014) and ESA CCI LC (ESA, 2017). To combination of MODIS land cover with $C$ values for agricultural land uses was performed as described in Panagos et al. (2015b). C values of non agricultural land uses were derived from Panagos et al. (2015b) and Borrelli et al. (2017) for MODIS LC. Panagos et al. (2015b) propose ranges of $C$ values for natural vegetation land uses and calculate the $C$ value in a location based on the vegetation density derived from MODIS VCF. For the ESA CCI LC product average $C$ values for non agricultural land uses were calculated based on the shares of a land cover described in the ESA CCI LC legend and the ranges of $C$ values proposed by Panagos et al. (2015b), similar to MODIS LC and MODIS VCF. The combination of $C$ factor values of crops and non agricultural land uses was performed accordingly:

$$
C_{(x, y)}=C_{C r o p,(x, y)} \cdot w_{C r o p,(x, y)}+C_{L C,(x, y)} \cdot w_{L C,(x, y)}
$$

where $C_{C r o p,(x, y)}$ and $C_{L C,(x, y)}$ are the $C$ values of the crop and the non agricultural land cover for the location $(x, y)$ and $w_{C r o p,(x, y)}$ and $w_{L C,(x, y)}$ are the respective weights values of the crop and the non agricultural land cover for the location $(x, y)$. The respective non agricultural $C$ factor values and weights for MODIS LC and ESA CCI LC can be found in the tables S.9 and S.10.

Table S.9: MODIS land cover classification linked with C factor ranges of the respective land cover and weights to calculate mixed $C$ values for shared landuses of non crop land cover and crops

\begin{tabular}{|c|c|c|c|c|c|}
\hline Value & Label & $C_{\min }$ & $C_{\max }$ & $w_{\text {Crop }}$ & $w_{L C}$ \\
\hline 0 & Water & - & - & 0 & 1 \\
\hline 1 & Evergreen Needleleaf forest & 0.0001 & 0.003 & 0 & 1 \\
\hline 2 & Evergreen Broadleaf forest & 0.0001 & 0.003 & 0 & 1 \\
\hline 3 & Deciduous Needleleaf forest & 0.0001 & 0.003 & 0 & 1 \\
\hline 4 & Deciduous Breoadleaf forest & 0.0001 & 0.003 & 0 & 1 \\
\hline 5 & Mixed forest & 0.0001 & 0.003 & 0 & 1 \\
\hline 6 & Closed shrublands & 0.01 & 0.15 & 0 & 1 \\
\hline 7 & Open shrublands & 0.01 & 0.15 & 0 & 1 \\
\hline 8 & Woody savannas & 0.01 & 0.15 & 0 & 1 \\
\hline 9 & Savannas & 0.01 & 0.15 & 0 & 1 \\
\hline 10 & Grasslands & 0.01 & 0.15 & 0 & 1 \\
\hline 11 & Permanent wetlands & - & - & 0 & 1 \\
\hline 12 & Croplands & 0 & 0 & 1 & 0 \\
\hline 13 & Urban built-up & - & - & 0 & 1 \\
\hline 14 & $\begin{array}{l}\text { Cropland/Natural vegetation } \\
\text { mosaic }\end{array}$ & 0.0001 & 0.05 & 0.8 & 0.2 \\
\hline 15 & Snow and ice & - & - & 0 & 1 \\
\hline 16 & Barren or sparsely vegetated & 0.1 & 0.5 & 0 & 1 \\
\hline 254 & Unclassified & - & - & 0 & 1 \\
\hline 255 & Fill Value & - & - & 0 & 1 \\
\hline
\end{tabular}


Table S.10: ESA land cover classification linked with C factor ranges of the respective land cover and weights to calculate mixed $C$ values for shared landuses of non crop land cover and crops

\begin{tabular}{|c|c|c|c|c|}
\hline Value & Label & $C_{L C}$ & $w_{\text {Crop }}$ & $w_{L C}$ \\
\hline 10 & Cropland & 0 & 1 & 0 \\
\hline 11 & Crop, herb cover & 0.1 & 0.8 & 0.2 \\
\hline 12 & Crop, Tree, shrub cover & 0.003 & 0.8 & 0.2 \\
\hline 20 & Crop irrigated or post flood & 0 & 1 & 0 \\
\hline 30 & $\begin{array}{l}\text { Mosaic cropland }(>50 \%) \text { / natural vegetation (tree, } \\
\text { shrub, herbaceous cover) }(<50 \%)\end{array}$ & 0.0265 & 0.75 & 0.25 \\
\hline 40 & $\begin{array}{l}\text { Mosaic natural vegetation (tree, shrub, herbaceous } \\
\text { cover }(>50 \%) / \text { cropland }(<50 \%)\end{array}$ & 0.0265 & 0.25 & 0.75 \\
\hline 50 & $\begin{array}{l}\text { Tree cover, broadleaved, evergreen, closed to open } \\
(>15 \%)\end{array}$ & 0.0016 & 0 & 1 \\
\hline 60 & $\begin{array}{l}\text { Tree cover, broadleaved, deciduous, closed to open } \\
(>15 \%)\end{array}$ & 0.0016 & 0 & 1 \\
\hline 61 & Tree cover, broadleaved, deciduous, closed (>40\%) & $4 \mathrm{e}-04$ & 0 & 1 \\
\hline 62 & Tree cover, broadleaved, deciduous, open $(15-40 \%)$ & 0.0027 & 0 & 1 \\
\hline 70 & $\begin{array}{l}\text { Tree cover, needleleaved, evergreen, closed to open } \\
(>15 \%)\end{array}$ & 0.0016 & 0 & 1 \\
\hline 90 & $\begin{array}{l}\text { Tree cover, mixed leaf type (broadleaved and } \\
\text { needleleaved) }\end{array}$ & $4 \mathrm{e}-04$ & 0 & 1 \\
\hline 100 & $\begin{array}{l}\text { Mosaic tree and shrub }(>50 \%) / \text { herbaceous cover } \\
(<50 \%)\end{array}$ & 0.08 & 0 & 1 \\
\hline 110 & $\begin{array}{l}\text { Mosaic herbaceous cover }(>50 \%) / \text { tree and shrub } \\
(<50 \%)\end{array}$ & 0.08 & 0 & 1 \\
\hline 120 & Shrubland & 0.08 & 0 & 1 \\
\hline 122 & Deciduous shrubland & 0.08 & 0 & 1 \\
\hline 130 & Grassland & 0.08 & 0 & 1 \\
\hline 150 & $\begin{array}{l}\text { Sparse vegetation (tree, shrub, herbaceous cover) } \\
(<15 \%)\end{array}$ & 0.3 & 0 & 1 \\
\hline 152 & Sparse shrub $(<15 \%)$ & 0.3 & 0 & 1 \\
\hline 153 & Sparse herbaceous cover $(<15 \%)$ & 0.4 & 0 & 1 \\
\hline 160 & Tree cover, flooded, fresh or brakish water & 0.003 & 0 & 1 \\
\hline 170 & Tree cover, flooded, saline water & 0.003 & 0 & 1 \\
\hline 180 & $\begin{array}{l}\text { Shrub or herbaceous cover, flooded, } \\
\text { fresh/saline/brakish water }\end{array}$ & 0.15 & 0 & 1 \\
\hline 190 & Urban areas & 0 & 0 & 1 \\
\hline 200 & Bare areas & 0.5 & 0 & 1 \\
\hline 201 & Consolidated bare areas & 0.15 & 0 & 1 \\
\hline 202 & Unconsolidated bare areas & 0.5 & 0 & 1 \\
\hline
\end{tabular}




\section{S.2 USLE model input factors - Summary statistics for individual realizations}

This section summarizes the individual realizations for the four analyzed USLE input factors to give a general overview. The following tables show quantile values of the USLE input realizations analyzed for the entire study area of Uganda and Kenya.

Table S.11: Summary statistics for the R factor realizations

\begin{tabular}{lrrrrrrrrr}
\hline Quantile & $R_{\text {Roose }}$ & $R_{\text {Moore }}$ & $R_{\text {Lo }}$ & $R_{\text {Renard }}$ & $R_{\text {Nakil }}$ & $R_{\text {Fenta }, P}$ & $R_{\text {Fenta, MFI }}$ & $R_{\text {TMPA }}$ & $R_{\text {GloREDa }}$ \\
\hline min & 1298 & 52.54 & 560.5 & 154 & 946.1 & 0 & 359.6 & 1.221 & 857.2 \\
q.25 & 3953 & 1774 & 1629 & 925.6 & 1210 & 1193 & 1796 & 2774 & 1943 \\
median & 6851 & 3652 & 2795 & 2243 & 1581 & 2696 & 2668 & 3956 & 3432 \\
q.75 & 9636 & 5458 & 3915 & 4324 & 2046 & 3897 & 3306 & 5463 & 4801 \\
max & 22741 & 13952 & 9187 & 25755 & 6875 & 9099 & 11982 & 31068 & 12930 \\
\hline
\end{tabular}

Table S.12: Summary statistics for the K factor realizations

\begin{tabular}{lrrrrrr}
\hline Quantile $K_{\text {Soilgr.,Wischm. }}$ & $K_{\text {Soilgr.,Will. }}$ & $K_{\text {Soilgr.,Torri }}$ & $K_{G S D E, \text { Wischm. }}$ & $K_{G S D E, \text { Will. }}$ & $K_{G S D E, \text { Torri }}$ \\
\hline min & 0.004999 & 0.01077 & 0.001 & $1 \mathrm{e}-04$ & 0.007642 & $1 \mathrm{e}-04$ \\
q.25 & 0.01711 & 0.02284 & 0.07642 & 0.01416 & 0.02318 & 0.0753 \\
median & 0.01931 & 0.02465 & 0.07997 & 0.01867 & 0.02738 & 0.08232 \\
q.75 & 0.0218 & 0.02696 & 0.08422 & 0.02576 & 0.03165 & 0.09243 \\
max & 0.03798 & 0.03933 & 0.109 & 0.05513 & 0.05214 & 0.1484 \\
\hline
\end{tabular}

Table S.13: Summary statistics for the LS factor realizations

\begin{tabular}{|c|c|c|c|c|c|c|}
\hline \multicolumn{2}{|c|}{ QuantileLS $S_{S R T M, M o o r e}$} & \multirow{2}{*}{$\begin{array}{r}L S_{S R T M, \text { Desmet }} \\
0.03\end{array}$} & \multirow{2}{*}{$\begin{array}{r}L S_{S R T M, \text { Boehner }} \\
0\end{array}$} & \multirow{2}{*}{$\begin{array}{c}S_{\text {ASTERMoore }} \\
0\end{array}$} & \multirow{2}{*}{$\begin{array}{r}L S_{\text {ASTER,Desmet }} \\
0.03\end{array}$} & \multirow{2}{*}{$\frac{L S_{\text {ASTER,Boehne }}}{0}$} \\
\hline $\min$ & 0 & & & & & \\
\hline q.25 & 0 & 0.1249 & 0 & 0 & 0.3187 & 0.06382 \\
\hline median & 0.01319 & 0.334 & 0.07447 & 0.1963 & 0.8278 & 0.1494 \\
\hline q.75 & 0.3196 & 0.9901 & 0.2377 & 0.8331 & 1.879 & 0.5966 \\
\hline $\max$ & 91.48 & 19.31 & 70.63 & 226.6 & 19.75 & 212.7 \\
\hline
\end{tabular}

Table S.14: Summary statistics for the $\mathrm{C}$ factor realizations

\begin{tabular}{lrrrrrr}
\hline Quantile & $C_{N D V I, \text { annual }}$ & $C_{\text {NDVI,rainy }}$ & $C_{E S A, \text { admin. }}$ & $C_{\text {ESA,Monfr. }}$ & $C_{\text {MODIS }}$ dmin. & $C_{\text {MODIS,Monfr. }}$. \\
\hline min & $8.715 \mathrm{e}-07$ & $5.874 \mathrm{e}-07$ & 0 & 0 & 0 & 0 \\
q.25 & 0.0591 & 0.04719 & 0.08 & 0.08 & 0.1498 & 0.1499 \\
median & 0.2137 & 0.1749 & 0.08 & 0.08 & 0.15 & 0.15 \\
q.75 & 0.4019 & 0.3546 & 0.15 & 0.232 & 0.15 & 0.15 \\
max & 1 & 1 & 0.5 & 0.5 & 0.5 & 0.5 \\
\hline
\end{tabular}




\section{S.3 Issues with LS factor calculation with ASTER DEM}

As outlined in the main document of this work, the realizations for the LS factor that used ASTER DEM (NASA/METI/AIST/Japan Spacesystems, and U.S./Japan ASTER Science Team, 2009) for their computation were excluded from the analyses as issues were encountered in the simulation results that stem from noise and artefacts in the ASTER DEM inout data. As a result, only three instead of six realizations for the LS factor were used. Fig. S1 shows the LS factor realizations that result from SRTM 90m (Jarvis et al., 2008) and ASTER DEM when employing the method of Desmet and Govers (1996) for the LS calculation. The panels a) and b) show the results for the entire study area. The panels c) and d) show the detail located in the North-East of Kenya. While the LS calculations using the SRTM show low values close to 0 for large regions where the terrain is overall flat, the LS realization that implemented the ASTER DEM shows (i) random, non-systematic noise (the yellow scatters in flat terrain with no noteworthy heterogeneity in landscape) and (ii) systematic errors (strips), which originate from satellite malfunction or issues in data processing. (i) and (ii) can be clearly seen in the detail showing the dry, north-eastern part of Kenya. Based on the identified noise patterns (among other patterns e.g. in northern Uganda, that are not shown in detail here) we decided to exclude the LS realizations that are based on the ASTER DEM from the set of LS realizations that were used in the analyses of the manuscript. Although not illustrated here, other methods to calculate the LS factor showed comparable results and supported the assumption that the visible errors result from the input DEM rather than from the computation method itself. 

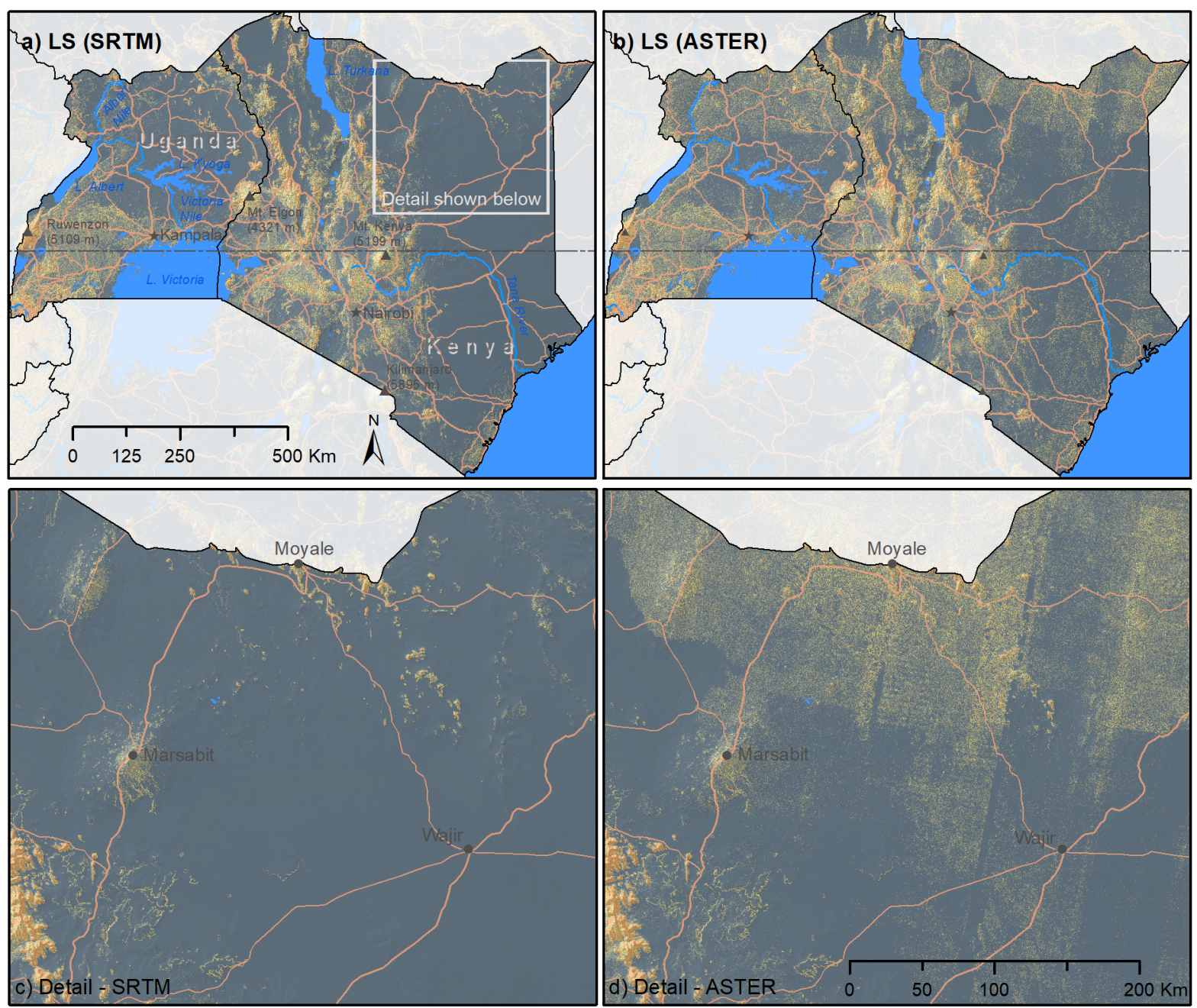

Slope length and steepness factor LS after Desmet and Govers (1996) using different DEM inputs (-)

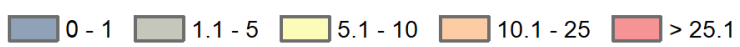

Data sources: Hillshade: SRTM 90m (Jarvis et al., 2008), ASTER GDEM V2 (NASA/METI/AIST/Japan Spacesystems, and U.S./Japan ASTER Science Team, 2009), Administrative boundaries, Cities, Roads, Water Surfaces and Rivers: naturalearthdata.com, Water Surfaces: Carroll et al. (2009)

Figure S.1: LS factor realizations that result from SRTM 90m (Jarvis et al., 2008) a) and ASTER DEM (NASA/METI/AIST/Japan Spacesystems, and U.S./Japan ASTER Science Team, 2009) b) when employing the method of Desmet and Govers (1996) for the LS calculation. The map detail indicated in panel a) is shown for SRTM 90m and ASTER DEM in the panels c) and d), respectively. ASTER based calculations show random and systematic noise in the detail in panel d). 


\section{S.4 Results for mean $C$ values on district level}

Implementing the crop shares from the agricultural surveys in Kenya (KNBS, 2015) and Uganda (UBOS, 2010) we calculated average $C$ factor values on district level employing the approach described in the previous section. The tables S.15 and S.16 summarise the calculated mean $C$ values for the districts of Kenya and Uganda, respectively.

Table S.15: Mean C factor values on district level for Kenya

\begin{tabular}{lr}
\hline District & $C_{\text {mean }}$ \\
\hline Baringo & 0.338 \\
Bomet & 0.315 \\
Bungoma & 0.339 \\
Busia & 0.332 \\
Elgeyo-Marakwet & 0.339 \\
Embu & 0.313 \\
Garissa & 0.226 \\
Homa Bay & 0.338 \\
Isiolo & 0.325 \\
Kajiado & 0.344 \\
Kakamega & 0.335 \\
Kericho & 0.357 \\
Kiambu & 0.358 \\
Kilifi & 0.288 \\
Kirinyaga & 0.325 \\
Kisii & 0.351 \\
Kisumu & 0.317 \\
Kitui & 0.33 \\
Kwale & 0.375 \\
Laikipia & 0.344 \\
Lamu & 0.293 \\
Machakos & 0.339 \\
Makueni & 0.344 \\
Mandera & 0.302 \\
Marsabit & 0.355 \\
Meru & 0.317 \\
Migori & 0.347 \\
Mombasa & 0.343 \\
Murang'a & 0.358 \\
Nairobi & 0.326 \\
Nakuru & 0.359 \\
Nandi & 0.297 \\
Nithi & 0.343 \\
Nyamira & 0.333 \\
Nyandarua & 0.333 \\
Nyeri &
\end{tabular}




\begin{tabular}{lr}
\hline District & $C_{\text {mean }}$ \\
\hline Samburu & 0.337 \\
Siaya & 0.355 \\
Taita Taveta & 0.331 \\
Tana River & 0.295 \\
Trans-Nzoia & 0.359 \\
Turkana & 0.266 \\
Uasin Gishu & 0.339 \\
Vihiga & 0.349 \\
Wajir & 0.28 \\
West Pokot & 0.354 \\
\hline
\end{tabular}

Table S.16: Mean C factor values on district level for Uganda

\begin{tabular}{lr}
\hline District & $C_{\text {mean }}$ \\
\hline Abim & 0.187 \\
Adjumani & 0.092 \\
Amolatar & 0.138 \\
Amuria & 0.148 \\
Amuru & 0.14 \\
Apac & 0.106 \\
Arua & 0.06 \\
Budaka & 0.104 \\
Bududa & 0.136 \\
Bugiri & 0.17 \\
Bukedea & 0.089 \\
Bukwo & 0.308 \\
Buliisa & 0.025 \\
Bundibugyo & 0.108 \\
Bushenyi & 0.151 \\
Busia & 0.113 \\
Butaleja & 0.119 \\
Dokolo & 0.135 \\
Gulu & 0.182 \\
Hoima & 0.095 \\
Ibanda & 0.156 \\
Iganga & 0.101 \\
Isingiro & 0.156 \\
Kinja & 0.122 \\
Kaabong & 0.262 \\
Kabarole & 0.171 \\
Kaberamaido & 0.145 \\
Kalangala & 0.131 \\
Kaliro & 0.158 \\
Kampala & 0.127 \\
& \\
\hline
\end{tabular}




\begin{tabular}{|c|c|}
\hline District & $C_{\text {mean }}$ \\
\hline Kamuli & 0.123 \\
\hline Kamwenge & 0.164 \\
\hline Kanungu & 0.178 \\
\hline Kapchorwa & 0.182 \\
\hline Kasese & 0.12 \\
\hline Katakwi & 0.153 \\
\hline Kayunga & 0.116 \\
\hline Kibaale & 0.171 \\
\hline Kiboga & 0.186 \\
\hline Kiruhura & 0.154 \\
\hline Kisoro & 0.197 \\
\hline Kitgum & 0.228 \\
\hline Koboko & 0.117 \\
\hline Kotido & 0.26 \\
\hline Kumi & 0.099 \\
\hline Kyenjojo & 0.157 \\
\hline Lira & 0.218 \\
\hline Luwero & 0.113 \\
\hline Lyantonde & 0.16 \\
\hline Manafwa & 0.178 \\
\hline Masaka & 0.145 \\
\hline Masindi & 0.191 \\
\hline Mayuge & 0.131 \\
\hline Mbale & 0.148 \\
\hline Mbarara & 0.152 \\
\hline Mityana & 0.171 \\
\hline Moroto & 0.248 \\
\hline Мoyo & 0.163 \\
\hline Mpigi & 0.149 \\
\hline Mubende & 0.175 \\
\hline Mukono & 0.123 \\
\hline Nakapiripirit & 0.246 \\
\hline Nakaseke & 0.158 \\
\hline Nakasongola & 0.06 \\
\hline Namutumba & 0.107 \\
\hline Nebbi & 0.041 \\
\hline Ntungamo & 0.173 \\
\hline Nyadri & 0.079 \\
\hline Oyam & 0.146 \\
\hline Pader & 0.239 \\
\hline Pallisa & 0.128 \\
\hline Rakai & 0.161 \\
\hline Rukungiri & 0.174 \\
\hline Sironko & 0.16 \\
\hline Soroti & 0.074 \\
\hline Ssembabule & 0.164 \\
\hline
\end{tabular}




\begin{tabular}{ll}
\hline District & $C_{\text {mean }}$ \\
\hline Tororo & 0.046 \\
Wakiso & 0.114 \\
Yumbe & 0.113 \\
\hline
\end{tabular}

\section{S.5 Results for soil loss on district level}

In this work the soil loss estimates that resulted from the USLE model ensemble was averaged on district level for all districts of Kenya and Uganda. In the main document only selected erosion prone districts were selected and analyzed with more detail. In the following we summarize the soil loss estimates for all districts of Kenya (Table S.17) and Uganda (Table S.18).

Table S.17: Quantiles of mean soil loss estimates for all Kenyan districts based on the 972 USLE model setups in tha $a^{-1} y r^{-1}$

\begin{tabular}{lrrrrrrrr}
\hline District & $A_{\text {min }}$ & $A_{0.025}$ & $A_{0.25}$ & $A_{\text {median }}$ & $A_{\text {mean }}$ & $A_{0.75}$ & $A_{0.975}$ & $A_{\text {max }}$ \\
\hline Baringo & 3.8 & 6.37 & 14.23 & 28.5 & 45.16 & 52.81 & 191.96 & 419.07 \\
Bomet & 0.28 & 0.74 & 4.66 & 20.95 & 46.71 & 59.13 & 243.26 & 535.72 \\
Bungoma & 2.24 & 4.02 & 14.23 & 29.4 & 53.83 & 68.77 & 253.74 & 478.27 \\
Busia & 0.14 & 0.37 & 2.13 & 5.76 & 13.27 & 14.42 & 84.66 & 176.16 \\
Busia & 0.42 & 1.01 & 5.98 & 16.68 & 34.26 & 46.3 & 187.06 & 326.36 \\
Elgeyo- & 2.21 & 4.15 & 20.54 & 47.21 & 85.2 & 110.6 & 381.12 & 797.47 \\
Marakwet & & & & & & & & \\
Embu & 1.43 & 3.49 & 11.85 & 24.3 & 45.26 & 55.41 & 216.03 & 398.7 \\
Garissa & 0.04 & 0.09 & 0.29 & 0.62 & 1.22 & 1.43 & 6.07 & 13.26 \\
Homa Bay & 1.27 & 2.96 & 12.98 & 25.4 & 49.39 & 64.17 & 241.87 & 460.75 \\
Isiolo & 0.31 & 0.46 & 1.35 & 2.7 & 5.11 & 5.79 & 24.15 & 58.87 \\
Kajiado & 1.03 & 1.47 & 3.89 & 7.68 & 12.98 & 15.6 & 55.57 & 138.84 \\
Kakamega & 0.57 & 1.32 & 7.71 & 20.23 & 42.55 & 53.18 & 229.32 & 423.42 \\
Kericho & 0.77 & 1.75 & 11.35 & 40.34 & 85.99 & 112.63 & 445.07 & 880.44 \\
Kiambu & 1.62 & 3.1 & 8.47 & 17.06 & 33.22 & 41.06 & 148.06 & 374.2 \\
Kilifi & 0.71 & 1.1 & 2.59 & 5.21 & 8.55 & 9.96 & 37.07 & 76.14 \\
Kirinyaga & 1.7 & 3.44 & 10.73 & 19.94 & 32.15 & 39.14 & 130.04 & 311.77 \\
Kisii & 0.45 & 1.4 & 11.03 & 41.69 & 87.38 & 112.13 & 478.9 & 855.23 \\
Kisumu & 0.77 & 1.67 & 8.2 & 18.87 & 36.78 & 48.58 & 179.19 & 312.46 \\
Kitui & 1.13 & 1.82 & 4.82 & 8.97 & 15.76 & 20.05 & 77.05 & 120.3 \\
Kwale & 1.08 & 1.74 & 4.26 & 8.38 & 14.26 & 16.58 & 65.69 & 131.82 \\
Laikipia & 1.67 & 2.7 & 5.78 & 12.16 & 19.15 & 22.38 & 77.39 & 154.36 \\
Lamu & 0.16 & 0.27 & 0.67 & 1.28 & 2.21 & 2.65 & 10.33 & 28.36 \\
Machakos & 2.21 & 3.27 & 8.91 & 17.72 & 29.72 & 36.16 & 140.89 & 268.93 \\
Makueni & 2.18 & 3.42 & 8.82 & 16.8 & 28.63 & 35.4 & 135.48 & 257.18 \\
Mandera & 0.15 & 0.28 & 0.89 & 1.98 & 4.08 & 4.67 & 18.59 & 52.47 \\
Marsabit & 0.24 & 0.44 & 1.39 & 3.23 & 6.21 & 6.98 & 28.61 & 77.57 \\
Meru & 4.35 & 6.23 & 15.49 & 29.6 & 47.43 & 55.31 & 208.95 & 381.88 \\
Migori & 0.72 & 1.83 & 8.79 & 20.35 & 40.86 & 52.09 & 207.99 & 401.34 \\
& & & & & & & &
\end{tabular}




\begin{tabular}{lrrrrrrrr}
\hline District & $A_{\text {min }}$ & $A_{0.025}$ & $A_{0.25}$ & $A_{\text {median }}$ & $A_{\text {mean }}$ & $A_{0.75}$ & $A_{0.975}$ & $A_{\text {max }}$ \\
\hline Mombasa & 0.24 & 0.53 & 2.85 & 5.82 & 11.92 & 14.11 & 56.94 & 144.75 \\
Murang'a & 0.91 & 2.4 & 13.75 & 32.42 & 64.47 & 74.91 & 298.77 & 736.36 \\
Nairobi & 0.6 & 0.99 & 2.49 & 4.96 & 8.19 & 9.67 & 30.22 & 62.62 \\
Nakuru & 1.98 & 3.55 & 10.32 & 19.15 & 34.75 & 42.17 & 137.92 & 327.17 \\
Nandi & 0.8 & 1.67 & 10.92 & 44.57 & 95.42 & 123.65 & 501.74 & 1044.62 \\
Narok & 1.94 & 3.8 & 9.94 & 18.79 & 31.77 & 38.16 & 122.35 & 278.61 \\
Nithi & 0.88 & 2.12 & 9.61 & 21.72 & 41.55 & 50.02 & 216.83 & 401.98 \\
Nyamira & 0.36 & 1.01 & 7.94 & 46.09 & 100.58 & 129.21 & 553.75 & 1049.56 \\
Nyandarua & 1.55 & 2.96 & 10.19 & 20.41 & 37.28 & 44.56 & 161.21 & 421.7 \\
Nyeri & 3.75 & 4.91 & 15.23 & 28.99 & 49.03 & 58.68 & 200.25 & 509.01 \\
Samburu & 2.93 & 4.28 & 11.13 & 21.12 & 35.95 & 43.86 & 149.83 & 364.36 \\
Siaya & 0.42 & 0.93 & 5.42 & 14.69 & 30.4 & 38.9 & 161.58 & 289.34 \\
Taita & 1.22 & 1.85 & 4.32 & 8.38 & 13.9 & 17.05 & 53.06 & 98.17 \\
Taveta & & & & & & & & \\
Tana & 0.12 & 0.2 & 0.57 & 1.14 & 2.21 & 2.55 & 10.38 & 26.09 \\
River & & & & & & & & \\
Trans- & 1.06 & 2.24 & 8.36 & 17.34 & 32.72 & 41.69 & 135.38 & 317.96 \\
Nzoia & & & & & & & & \\
Turkana & 0.63 & 1.16 & 4.21 & 8.84 & 17.56 & 20.1 & 87.18 & 235.97 \\
Uasin & 0.45 & 1.32 & 5.04 & 11.16 & 20.91 & 26.36 & 92.86 & 194.55 \\
Gishu & & & & & & & & \\
Vihiga & 1.01 & 2.43 & 14.82 & 42.74 & 90.58 & 116.79 & 490.03 & 894.4 \\
Wajir & 0.05 & 0.1 & 0.36 & 0.84 & 1.7 & 2.01 & 7.96 & 22.51 \\
West & 5.7 & 8.19 & 19.57 & 38.27 & 62.83 & 74.23 & 282.83 & 658.77 \\
Pokot & & & & & & & & \\
\hline & & & & & & & &
\end{tabular}

Table S.18: Quantiles of mean soil loss estimates for all Ugandan districts based on the 972 USLE model setups in tha $a^{-1} \mathrm{yr}^{-1}$

\begin{tabular}{lrrrrrrrr}
\hline District & $A_{\text {min }}$ & $A_{0.025}$ & $A_{0.25}$ & $A_{\text {median }}$ & $A_{\text {mean }}$ & $A_{0.75}$ & $A_{0.975}$ & $A_{\text {max }}$ \\
\hline Abim & 0.45 & 0.87 & 3.77 & 9.32 & 19.57 & 20.93 & 111.83 & 266.39 \\
Adjumani & 0.17 & 0.4 & 1.39 & 3.54 & 8.27 & 8.56 & 51.3 & 135.02 \\
Amolatar & 0.14 & 0.32 & 1 & 1.96 & 3.81 & 4.45 & 20.53 & 47.31 \\
Amuria & 0.32 & 0.48 & 1.34 & 2.74 & 4.6 & 5.56 & 20.97 & 47.91 \\
Amuru & 0.25 & 0.61 & 2.15 & 4.73 & 9.51 & 11.26 & 51.36 & 125.75 \\
Apac & 0.11 & 0.25 & 1.1 & 2.45 & 5.38 & 6.17 & 32.21 & 71.53 \\
Arua & 0.52 & 1.09 & 3.48 & 7.76 & 15.51 & 18.14 & 87.64 & 218.54 \\
Budaka & 0.26 & 0.51 & 1.53 & 3.46 & 6.72 & 7.55 & 36.1 & 83.14 \\
Bududa & 7.2 & 16.99 & 48.59 & 90.69 & 138.78 & 173.71 & 544.75 & 1080.05 \\
Bugiri & 0.18 & 0.44 & 2.18 & 5.8 & 12.62 & 15.63 & 72.79 & 144.78 \\
Bukedea & 0.29 & 0.4 & 1.07 & 2.54 & 4.65 & 5.62 & 24.03 & 57.89 \\
Bukwo & 4.01 & 6.71 & 18.91 & 40.58 & 71.78 & 83.36 & 346.17 & 862.47 \\
Buliisa & 0.34 & 0.69 & 1.8 & 3.63 & 6.62 & 7.74 & 32.8 & 81.8 \\
Bundibugyo & 2.77 & 4.81 & 11.56 & 22.82 & 35.2 & 42.36 & 149.53 & 351.58
\end{tabular}




\begin{tabular}{|c|c|c|c|c|c|c|c|c|}
\hline District & $A_{\min }$ & $A_{0.025}$ & $A_{0.25}$ & $A_{\text {median }}$ & $A_{\text {mean }}$ & $A_{0.75}$ & $A_{0.975}$ & $A_{\max }$ \\
\hline Bushenyi & 0.83 & 1.62 & 8.15 & 21.92 & 45.47 & 55.09 & 234.39 & 581.16 \\
\hline Busia & 0.14 & 0.37 & 2.13 & 5.76 & 13.27 & 14.42 & 84.66 & 176.16 \\
\hline Busia & 0.42 & 1.01 & 5.98 & 16.68 & 34.26 & 46.3 & 187.06 & 326.36 \\
\hline Butaleja & 0.09 & 0.22 & 1.05 & 2.32 & 4.94 & 5.46 & 26.27 & 70.94 \\
\hline Dokolo & 0.23 & 0.49 & 1.65 & 3.26 & 6.56 & 7.63 & 36.51 & 82.59 \\
\hline Gulu & 0.17 & 0.43 & 1.56 & 3.66 & 7.27 & 8.25 & 43.18 & 94.47 \\
\hline Hoima & 0.38 & 0.86 & 3.58 & 8.73 & 18.36 & 20.3 & 107.23 & 263.87 \\
\hline Ibanda & 0.56 & 1.18 & 7.3 & 22.89 & 48.91 & 61.11 & 255.55 & 638.36 \\
\hline Iganga & 0.1 & 0.25 & 1.47 & 4.19 & 10.02 & 10.68 & 58.44 & 141.16 \\
\hline Isingiro & 1.31 & 2.96 & 10.81 & 21.64 & 39.31 & 48.51 & 176.13 & 440.66 \\
\hline Jinja & 0.35 & 0.77 & 3.83 & 10.23 & 21.65 & 25.05 & 122.2 & 260.94 \\
\hline Kaabong & 1.35 & 2.08 & 7.9 & 15.31 & 30.26 & 35.03 & 140.63 & 417.29 \\
\hline Kabale & 6.33 & 11.42 & 38.18 & 75.16 & 139.47 & 168.4 & 591.69 & 1528.61 \\
\hline Kabarole & 3.51 & 5.83 & 17.44 & 31.97 & 58.4 & 71.15 & 252.52 & 679.17 \\
\hline Kaberamaido & 0.15 & 0.34 & 1.37 & 2.65 & 5.67 & 6.57 & 32.23 & 72.59 \\
\hline Kalangala & 0.44 & 0.83 & 2.37 & 4.56 & 7.47 & 9.24 & 29.94 & 77.59 \\
\hline Kaliro & 0.19 & 0.43 & 1.59 & 3.09 & 6.62 & 7.83 & 37.97 & 76.33 \\
\hline Kampala & 0.36 & 0.9 & 2.84 & 5.78 & 10.47 & 12.18 & 48.75 & 134.17 \\
\hline Kamuli & 0.13 & 0.31 & 1.32 & 3.13 & 6.88 & 7.94 & 38.47 & 94.85 \\
\hline Kamwenge & 0.24 & 0.52 & 3.37 & 11.81 & 26.91 & 34.51 & 142.76 & 362.28 \\
\hline Kanungu & 1.03 & 2.17 & 11.96 & 29.16 & 58.95 & 72.99 & 281.56 & 716.8 \\
\hline Kapchorwa & 3.73 & 5.72 & 18.18 & 35.99 & 59.51 & 69.22 & 273.16 & 683.5 \\
\hline Kasese & 5.87 & 9.7 & 28.24 & 54.78 & 100.06 & 116.5 & 462.94 & 1456 \\
\hline Katakwi & 0.15 & 0.31 & 0.84 & 1.73 & 2.85 & 3.37 & 12.85 & 31.6 \\
\hline Kayunga & 0.06 & 0.14 & 0.75 & 2.66 & 6.36 & 7.38 & 36.85 & 95.09 \\
\hline Kibaale & 0.12 & 0.27 & 1.84 & 12.02 & 27.74 & 34.26 & 154.96 & 440.75 \\
\hline Kiboga & 0.11 & 0.25 & 1.79 & 7.42 & 16.46 & 21.55 & 85.2 & 184.72 \\
\hline Kiruhura & 0.28 & 0.6 & 3.51 & 7.98 & 17.86 & 21.22 & 93.63 & 219.21 \\
\hline Kisoro & 4.17 & 7.66 & 26.4 & 55.33 & 104.63 & 123.9 & 502.82 & 1176.19 \\
\hline Kitgum & 0.35 & 0.63 & 2.1 & 5.31 & 11.36 & 12.15 & 66.64 & 175.6 \\
\hline Koboko & 0.5 & 1.14 & 4.08 & 8.58 & 17.76 & 21.09 & 96.81 & 255.96 \\
\hline Kotido & 0.26 & 0.43 & 1.3 & 2.44 & 4.67 & 5.45 & 20.23 & 54.87 \\
\hline Kumi & 0.38 & 0.49 & 1.39 & 3.16 & 5.5 & 6.76 & 26.77 & 61.62 \\
\hline Kyenjojo & 0.08 & 0.21 & 1.53 & 12.67 & 29.33 & 37.14 & 156.18 & 408.83 \\
\hline Lira & 0.25 & 0.58 & 2.01 & 3.76 & 7.04 & 8.96 & 33.35 & 68.17 \\
\hline Luwero & 0.05 & 0.1 & 0.65 & 4.44 & 10.47 & 12.61 & 61.59 & 143.92 \\
\hline Lyantonde & 0.45 & 1.05 & 4.76 & 10.64 & 21.62 & 24.96 & 113.22 & 280.43 \\
\hline Manafwa & 2.82 & 6.27 & 21.94 & 43.16 & 75.25 & 92.97 & 334.56 & 784.16 \\
\hline Masaka & 0.43 & 0.9 & 4.4 & 10.18 & 20.53 & 24.71 & 100.07 & 222.03 \\
\hline Masindi & 0.11 & 0.28 & 1.56 & 4.62 & 10.04 & 12.67 & 54.43 & 118.38 \\
\hline Mayuge & 0.24 & 0.6 & 2.76 & 7.64 & 16.94 & 19.9 & 96.49 & 224.54 \\
\hline Mbale & 0.8 & 1.86 & 8.88 & 20.37 & 39.45 & 47.56 & 192.09 & 491.53 \\
\hline Mbarara & 1.17 & 2.4 & 10.83 & 22.35 & 44.29 & 53.06 & 216.08 & 537.82 \\
\hline Mityana & 0.11 & 0.24 & 1.38 & 13.11 & 29.6 & 37.63 & 163.1 & 421.42 \\
\hline Moroto & 0.34 & 0.54 & 2.61 & 6.22 & 12.15 & 14.5 & 54.41 & 143.37 \\
\hline Moyo & 0.75 & 1.54 & 5 & 11.57 & 23.45 & 25.48 & 128.32 & 348.41 \\
\hline
\end{tabular}




\begin{tabular}{lrrrrrrrr}
\hline District & $A_{\text {min }}$ & $A_{0.025}$ & $A_{0.25}$ & $A_{\text {median }}$ & $A_{\text {mean }}$ & $A_{0.75}$ & $A_{0.975}$ & $A_{\text {max }}$ \\
\hline Mpigi & 0.17 & 0.4 & 2.48 & 9.51 & 21.05 & 26.32 & 117.76 & 266.3 \\
Mubende & 0.13 & 0.32 & 2.34 & 14.12 & 32.39 & 40.82 & 179.79 & 483.67 \\
Mukono & 0.25 & 0.57 & 2.87 & 9.73 & 22.68 & 27.35 & 135.69 & 283.77 \\
Nakapiripirit & 0.61 & 1.18 & 3.43 & 6.65 & 12.36 & 15.37 & 53.39 & 131.04 \\
Nakaseke & 0.08 & 0.16 & 1 & 3.06 & 6.69 & 8.38 & 37.5 & 82.68 \\
Nakasongola & 0.11 & 0.18 & 0.59 & 1.34 & 2.93 & 3.24 & 14.96 & 49.23 \\
Namutumba & 0.19 & 0.42 & 1.6 & 3.61 & 7.82 & 8.27 & 46.96 & 98.26 \\
Nebbi & 0.72 & 1.42 & 4.41 & 10.73 & 21.97 & 23.54 & 130.48 & 320.27 \\
Ntungamo & 1.55 & 3.24 & 13.54 & 27.23 & 51.78 & 63.08 & 233.03 & 589.4 \\
Nyadri & 0.69 & 1.33 & 4.36 & 9.5 & 17.84 & 20.65 & 89.71 & 245.9 \\
Oyam & 0.1 & 0.22 & 1.19 & 2.95 & 6.65 & 7.86 & 36.78 & 85.58 \\
Pader & 0.16 & 0.32 & 1.23 & 3.19 & 6.52 & 6.5 & 40.92 & 91.25 \\
Pallisa & 0.25 & 0.51 & 1.56 & 3.25 & 6.15 & 7.1 & 31.89 & 75.11 \\
Rakai & 0.83 & 1.59 & 6.37 & 13.15 & 25.6 & 30.5 & 127.61 & 289.09 \\
Rukungiri & 0.87 & 1.7 & 9.16 & 23.16 & 47.04 & 56.62 & 226.57 & 555.65 \\
Sironko & 3.02 & 5.88 & 17.71 & 34.32 & 54.44 & 68.44 & 214.86 & 512.23 \\
Soroti & 0.27 & 0.43 & 1.23 & 2.96 & 5.43 & 6.18 & 31.19 & 67.77 \\
Ssembabule & 0.18 & 0.45 & 2.94 & 7.78 & 16.82 & 19.53 & 89.37 & 226.69 \\
Tororo & 0.3 & 0.49 & 1.61 & 4.46 & 10.21 & 10.28 & 69.82 & 152 \\
Wakiso & 0.36 & 0.75 & 3.77 & 9.96 & 22.18 & 25.48 & 128.6 & 283.77 \\
Yumbe & 0.26 & 0.64 & 2.12 & 4.44 & 8.68 & 10.26 & 43.56 & 129.48 \\
\hline & & & & & & & &
\end{tabular}

The distributions of the mean soil losses that resulted from all 972 USLE model realizations are additionally plotted for the districts of Kenya and Uganda in the figures S.2 and S.3. 


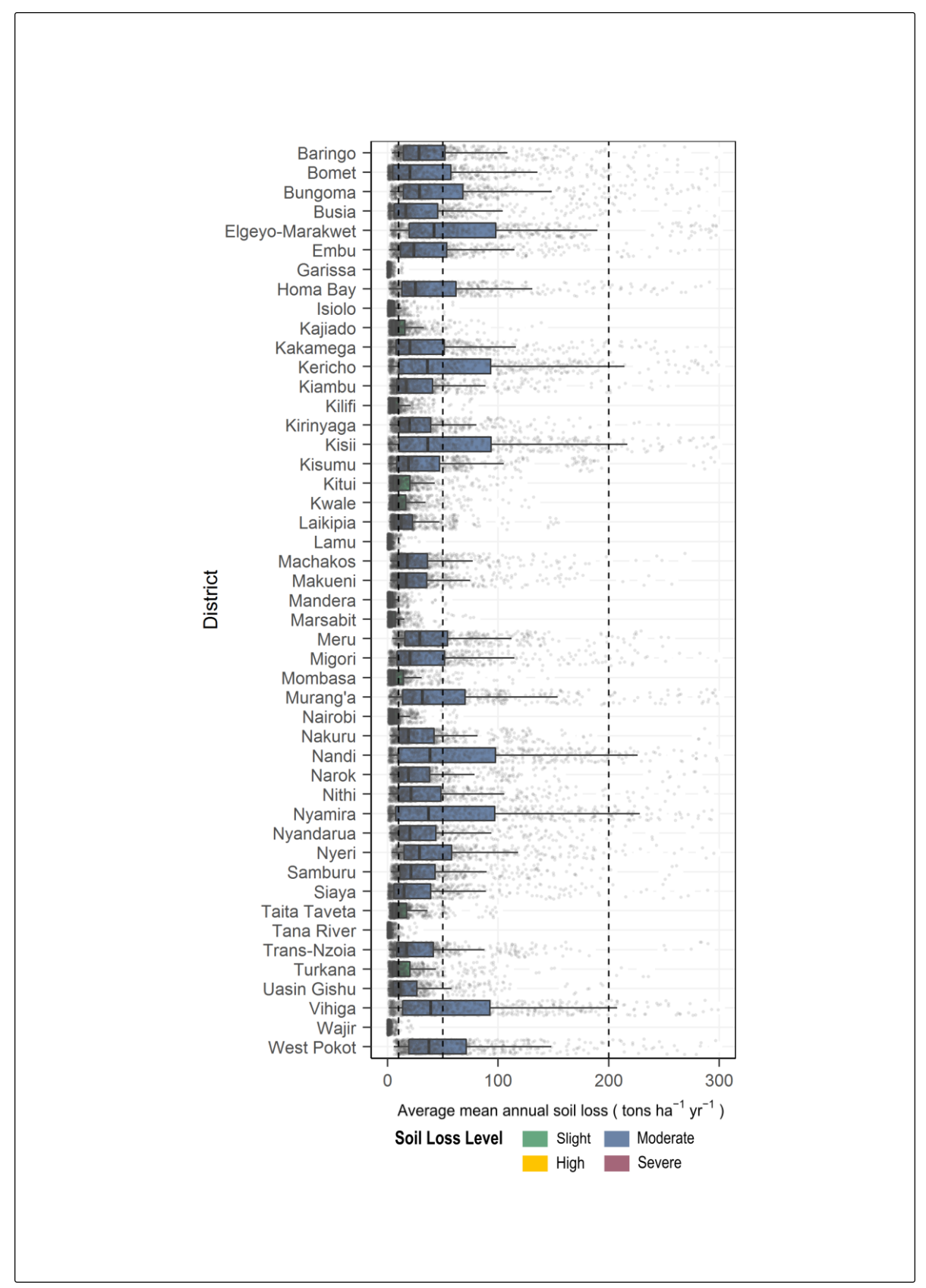

Figure S.2: Mean soil loss in the districts of Kenya. The grey dots show the estimated soil losses from all 972 USLE realizations. The boxplots represent the quantiles for the district results. 


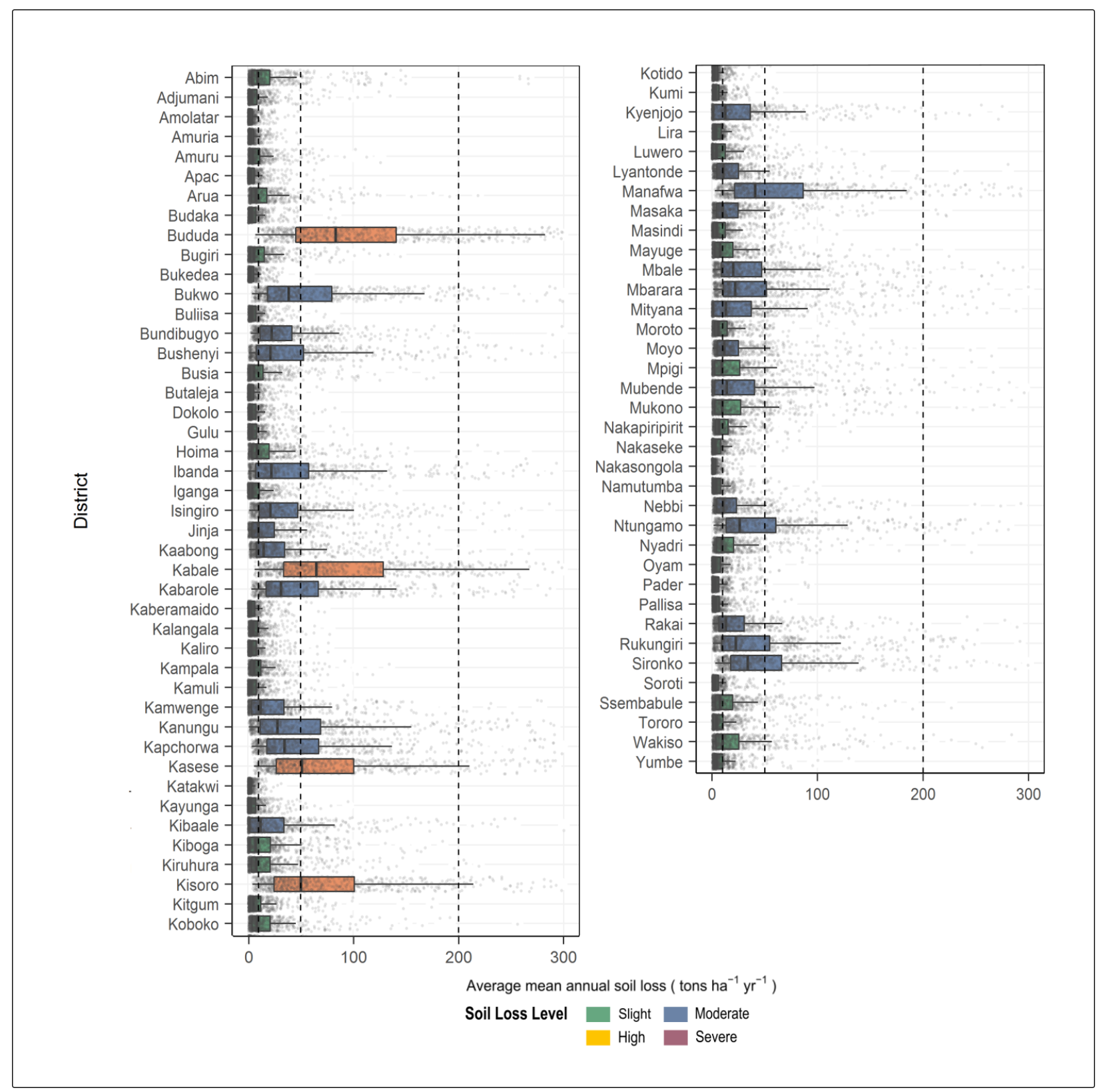

Figure S.3: Mean soil loss in the districts of Uganda. The grey dots show the estimated soil losses from all 972 USLE realizations. The boxplots represent the quantiles for the district results. 


\section{S.6 Sensitivity of soil loss estimates to individual input factors}

Fig. 7 in the main document illustrates the spatial distribution of the most important USLE input factors for the computation of the soil loss. Fig. S4 shows the indvidual results for the sensitivity index for all four USLE inputs that were analyzed. The dominant patterns that are also visible in Fig. 7 are also shown by the individual results. While particularly the $C$ factor shows large values in the highly vegetated areas in Uganda, patterns ther result from the soil input data are visible for the $\mathrm{K}$ factor in the dry regions of northern Kenya. The LS factor shows highly hetrogenious patterns in the entire study area that is also visible in Fig. 7. Although the R factor shows an overall high sensitivity and a low variability for the entire study region it is not as sensitive as other inputs and thus identified as the most dominant input in Fig. 7.
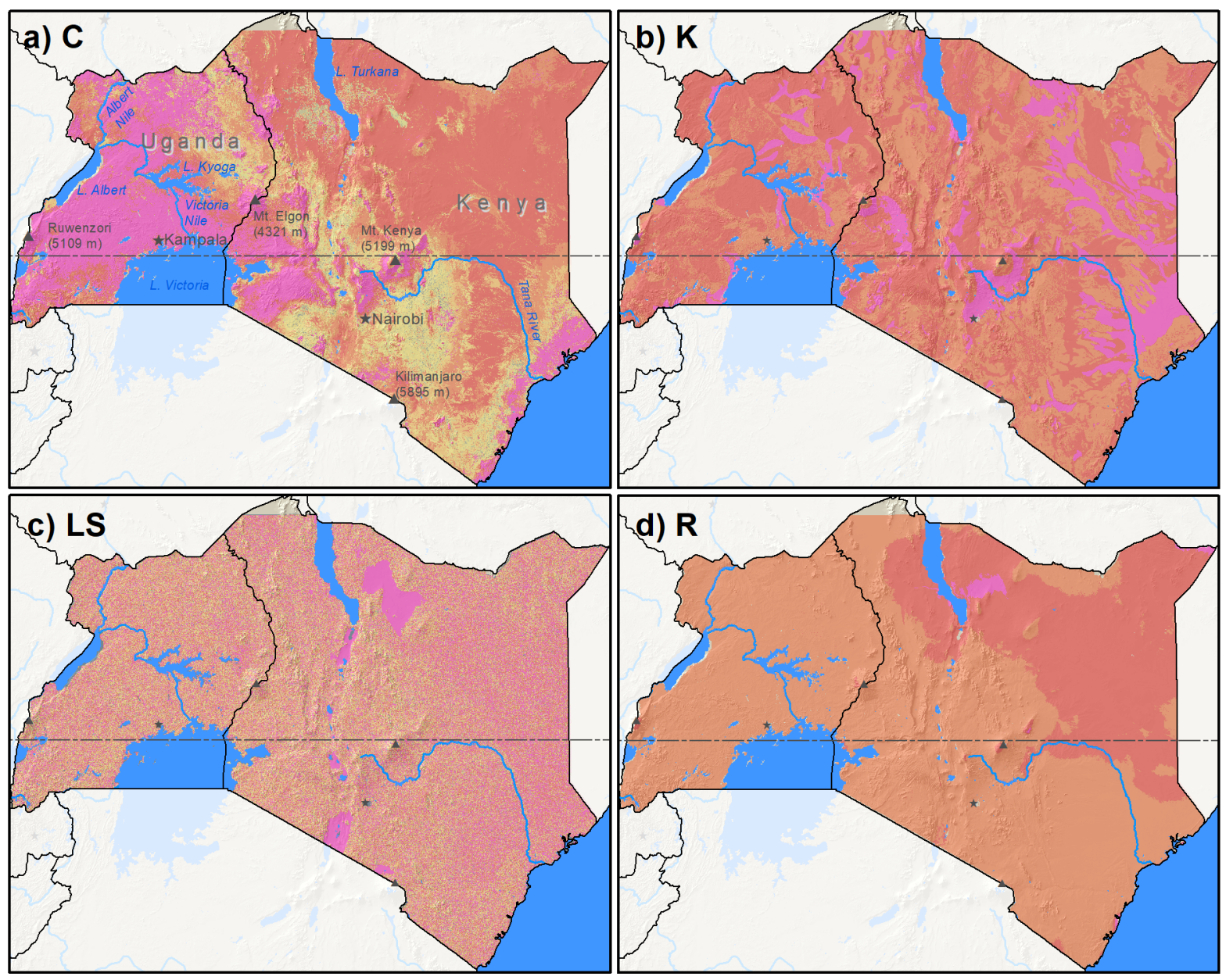

Importance of single input factors (\%) Basis: 972 realisations
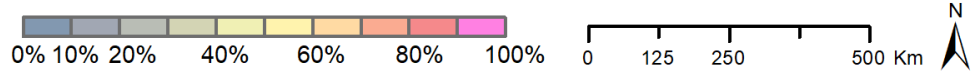

Data sources: Hillshade: SRTM $90 \mathrm{~m}$ (Jarvis et al., 2008), Administrative boundaries, Cities, Water Surfaces and Rivers: naturalearthdata.com Water Surfaces: Carroll et al. (2009)

Figure S.4: Results for the sensitivity index calculated for all four USLE input factors. 


\section{References}

Angima, S. D., Stott, D. E., O’Neill, M. K., Ong, C. K. and Weesies, G. A.: Soil erosion prediction using RUSLE for central Kenyan highland conditions, Agriculture, Ecosystems and Environment, 97(1-3), 295-308, doi:10.1016/S0167-8809(03)00011-2, 2003.

Arnoldus, H. M. J.: An approximation of the rainfall factor in the Universal Soil Loss Equation., in Assessment of erosion, edited by M. De Boodt and D. Gabriels, pp. 127-132, John Wiley \& Sons, Ltd., Chichester, UK., 1980.

Baruth, B., Genovese, G. and Montanarella, L., Eds.: Pedo-transfer rule 5 (PTR05): top soil structure class (STS), in New soil information for the mars crop yield forecasting system, European Commission, Joint Research Centre (EC JRC). [online] Available from: https://esdac.jrc.ec. europa.eu/Projects/SINFO/pdf/annex4_5.pdf, 2006.

Borrelli, P., Robinson, D. A., Fleischer, L. R., Lugato, E., Ballabio, C., Alewell, C., Meusburger, K., Modugno, S., Schütt, B., Ferro, V., Bagarello, V., Oost, K. V., Montanarella, L. and Panagos, P.: An assessment of the global impact of 21st century land use change on soil erosion, Nature Communications, 8(1), doi:10.1038/s41467-017-02142-7, 2017.

Bosco, C., De Rigo, D., Dewitte, O., Poesen, J. and Panagos, P.: Modelling soil erosion at European scale: Towards harmonization and reproducibility, Natural Hazards and Earth System Sciences, 15(2), 225-245, doi:10.5194/nhess-15-225-2015, 2015.

Böhner, J. and Selige, T.: Spatial prediction of soil attributes using terrain analysis and climate regionalisation, in 'SAGA - analysis and modelling applications', edited by J. Böhner, K. McCloy, and J. Strobl, Göttinger Geographische Abhandlungen, Göttingen, 13-28., 2006.

Channan, S., Collins, K. and Emanuel, W. R.: Global mosaics of the standard MODIS land cover type data, 2014.

Conrad, O., Bechtel, B., Bock, M., Dietrich, H., Fischer, E., Gerlitz, L., Wehberg, J., Wichmann, V. and Böhner, J.: System for automated geoscientific analyses (SAGA) v. 2.1.4, Geoscientific Model Development, 8(7), 1991-2007, doi:10.5194/gmd-8-1991-2015, 2015.

Desmet, P. and Govers, G.: A gis procedure for automatically calculating the usle ls factor on topographically complex landscape units, Journal of soil and water conservation, 51(5), 427433, 1996.

Didan, K.: MOD13Q1 modis/terra vegetation indices 16-day 13 global 250m sin grid v006, NASA EOSDIS Land Processes DAAC, doi:10.5067/MODIS/MOD13Q1.006, 2015.

ESA: ESA land cover climate change initiative (esa lc cci), via centre for environmental data analysis, [online] Available from: http:/ / maps.elie.ucl.ac.be/CCI, 2017.

ESRI: ArcGIS Desktop: Release 10.1, 2012.

Fenta, A. A., Yasuda, H., Shimizu, K., Haregeweyn, N., Kawai, T., Sultan, D., Ebabu, K. and Belay, A. S.: Spatial distribution and temporal trends of rainfall and erosivity in the eastern africa region, Hydrological Processes, 31(25), 4555-4567, doi:10.1002/hyp.11378, 2017.

Fenta, A. A., Tsunekawa, A., Haregeweyn, N., Poesen, J., Tsubo, M., Borrelli, P., Panagos, P., Vanmaercke, M., Broeckx, J., Yasuda, H., Kawai, T. and Kurosaki, Y.: Land susceptibility to water and wind erosion risks in the east africa region, Science of The Total Environment, 703, 135016, doi:10.1016/j.scitotenv.2019.135016, 2020.

Ferro, V., Giordano, G. and Iovino, M.: Isoerosivity and erosion risk map for sicily, Hydrological Sciences Journal, 36(6), 549-564, doi:10.1080/02626669109492543, 1991. 
Fick, S. E. and Hijmans, R. J.: WorldClim 2: new 1-km spatial resolution climate surfaces for global land areas, International Journal of Climatology, 37(12), 4302-4315, doi:10.1002/joc.5086, 2017.

Freeman, T.: Calculating catchment area with divergent flow based on a regular grid, Computers \& Geosciences, 17(3), 413-422, doi:10.1016/0098-3004(91)90048-i, 1991.

Hengl, T., De Jesus, J. M., Heuvelink, G. B., Gonzalez, M. R., Kilibarda, M., Blagotić, A., Shangguan, W., Wright, M. N., Geng, X., Bauer-Marschallinger, B., Guevara, M. A., Vargas, R., MacMillan, R. A., Batjes, N. H., Leenaars, J. G., Ribeiro, E., Wheeler, I., Mantel, S. and Kempen, B.: SoilGrids250m: Global gridded soil information based on machine learning, PLoS ONE, 12(2), 1-40, doi:10.1371/journal.pone.0169748, 2017.

Jarvis, A., Reuter, H. I., Nelson, A. and Guevara, E.: Hole-filled srtm for the globe version 4. [online] Available from: https:/ / cgiarcsi.community/data/srtm-90m-digital-elevation-databasev4-1/, 2008.

Karamage, F., Zhang, C., Liu, T., Maganda, A. and Isabwe, A.: Soil erosion risk assessment in Uganda, Forests, 8(2), 52, doi:10.3390/f8020052, 2017.

KNBS: Section agriculture, in County statistical abstracts, Kenya National Bureau of Statistics, Nairobi, Kenya., 2015.

Lo, A., El-Swaify, S. A., Dangler, E. W. and Shinshiro, L.: Effectiveness of EI30 as an erosivity index in Hawaii, in Soil erosion and conservation, edited by S. A. El-Swaify, W. C. Moldenhauer, and A. Lo, pp. 384-392, Soil Conservation Society of America, Ankeny, IA, USA., 1985.

Monfreda, C., Ramankutty, N. and Foley, J. A.: Farming the planet: 2. Geographic distribution of crop areas, yields, physiological types, and net primary production in the year 2000, Global Biogeochemical Cycles, 22(1), 1-19, doi:10.1029/2007GB002947, 2008.

Moore, I. D., Grayson, R. B. and Ladson, A. R.: Digital terrain modelling: A review of hydrological, geomorphological, and biological applications, Hydrological Processes, 5(1), 3-30, doi:10.1002/hyp.3360050103, 1991.

Moore, T. R.: Rainfall Erosivity in East Africa, Geografiska Annaler. Series A, Physical Geography, 61(3/4), 147-156, doi:10.2307/520909, 1979.

Morgan, R. P. C.: Soil erosion and conservation, John Wiley \& Sons., 2009.

Naipal, V., Reick, C., Pongratz, J. and Van Oost, K.: Improving the global applicability of the RUSLE model - Adjustment of the topographical and rainfall erosivity factors, Geoscientific Model Development, 8(9), 2893-2913, doi:10.5194/gmd-8-2893-2015, 2015.

Nakil, M.: Analysis of parameters causing water induced soil erosion, in Unpublished fifth annual progress seminar, indian institute of technology, bombay., 2014.

NASA/METI/AIST/Japan Spacesystems, and U.S./Japan ASTER Science Team: ASTER Global Digital Elevation Model., 2009.

Panagos, P., Meusburger, K., Ballabio, C., Borrelli, P. and Alewell, C.: Soil erodibility in Europe: A high-resolution dataset based on LUCAS, Science of the Total Environment, 479-480(1), 189200, doi:10.1016/j.scitotenv.2014.02.010, 2014.

Panagos, P., Borrelli, P. and Meusburger, K.: A New European Slope Length and Steepness Factor (LS-Factor) for Modeling Soil Erosion by Water, Geosciences, 5(2), 117-126, doi:10.3390/geosciences5020117, 2015a.

Panagos, P., Borrelli, P., Meusburger, K., Alewell, C., Lugato, E. and Montanarella, L.: Estimating the soil erosion cover-management factor at the European scale, Land Use Policy, 48, 38-50, doi:10.1016/j.landusepol.2015.05.021, 2015b. 
Panagos, P., Borrelli, P., Poesen, J., Ballabio, C., Lugato, E., Meusburger, K., Montanarella, L. and Alewell, C.: The new assessment of soil loss by water erosion in Europe, Environmental Science and Policy, 54, 438-447, doi:10.1016/j.envsci.2015.08.012, 2015c.

Panagos, P., Borrelli, P., Meusburger, K., Yu, B., Klik, A., Jae Lim, K., Yang, J. E., Ni, J., Miao, C., Chattopadhyay, N., Sadeghi, S. H., Hazbavi, Z., Zabihi, M., Larionov, G. A., Krasnov, S. F., Gorobets, A. V., Levi, Y., Erpul, G., Birkel, C., Hoyos, N., Naipal, V., Oliveira, P. T. S., Bonilla, C. A., Meddi, M., Nel, W., Al Dashti, H., Boni, M., Diodato, N., Van Oost, K., Nearing, M. and Ballabio, C.: Global rainfall erosivity assessment based on high-temporal resolution rainfall records, Scientific Reports, 7(1), 4175, doi:10.1038/s41598-017-04282-8, 2017.

Quinn, P., Beven, K., Chevallier, P. and Planchon, O.: The prediction of hillslope flow paths for distributed hydrological modelling using digital terrain models, Hydrological Processes, 5(1), 59-79, doi:10.1002/hyp.3360050106, 1991.

Renard, K. G. and Freimund, J. R.: Using monthly precipitation data to estimate the R-factor in the revised USLE, Journal of Hydrology, 157(1-4), 287-306, doi:10.1016/0022-1694(94)90110-4, 1994.

Roose, E. J.: Erosion et ruissellement en afrique de l'Ouest : Vingt années de mesures en petites parcelles expérimentales, Office de la scientifique et Technique Outre-Mer, Centre D'Adiopodoumé, Côte d'Ivoire., 1975.

Shangguan, W., Dai, Y., Duan, Q., Liu, B. and Yuan, H.: A global soil data set for earth system modeling, Journal of Advances in Modeling Earth Systems, 6, 249-263, doi:10.1002/2013MS000293, 2014.

Tamene, L. and Le, Q. B.: Estimating soil erosion in sub-Saharan Africa based on landscape similarity mapping and using the revised universal soil loss equation (RUSLE), Nutrient Cycling in Agroecosystems, 102(1), 17-31, doi:10.1007/s10705-015-9674-9, 2015.

Torri, D., Poesen, J. W. A. and Borselli, L.: Predictability and uncertainty of the soil erodibility factor using a global dataset, CATENA, 31, 1-22, doi:https:/ / doi.org/10.1016/S0341-8162(97)000362, 1997.

UBOS: Volume IV: Crop Area and Production Report, in Uganda census of agriculture 2008/2009, p. 178, Uganda Bureau of Statistics, Kampala, Uganda., 2010.

Van der Knijff, J., Jones, R. and Montanarella, L.: Soil Erosion Risk Assessment in Europe, EUR 19044 EN., European Soil Bureau, European Comission., 2000.

Vrieling, A., Hoedjes, J. C. B. and Velde, M. van der: Towards large-scale monitoring of soil erosion in Africa: Accounting for the dynamics of rainfall erosivity, Global and Planetary Change, 115, 33-43, doi:10.1016/j.gloplacha.2014.01.009, 2014.

Wang, L. and Liu, H.: An efficient method for identifying and filling surface depressions in digital elevation models for hydrologic analysis and modelling, International Journal of Geographical Information Science, 20(2), 193-213, doi:10.1080/13658810500433453, 2006.

Williams, J. R.: The EPIC model - Soil Erosion, in Computer models of watershed hydrology, edited by V. P. Singh, pp. 909-1000, Water Resources Publications, Highlands Ranch, CO, USA., 1995.

Wischmeier, W. H. and Smith, D. D.: Predicting rainfall erosion losses - a guide to conservation planning., USDA, Hyattsville, Maryland., 1987.

Yang, D., Kanae, S., Oki, T., Koike, T. and Musiake, K.: Global potential soil erosion with reference to land use and climate changes, Hydrological Processes, 17(14), 2913-2928, doi:10.1002/hyp.1441, 
2003.

Yu, B. and Rosewell, C.: A robust estimators of the R-factor for the Universal Soil Loss Equation, American Society of Agricultural Engineers, 39(2), 559-561, doi:https:/ / doi.org/10.13031/2013.27535, 1996.

Zevenbergen, L. W. and Thorne, C. R.: Quantitative analysis of land surface topography, Earth Surface Processes and Landforms, 12(1), 47-56, doi:10.1002/esp.3290120107, 1987. 